South Africa Working Paper No. 2

\title{
LAND TENURE ON THE ARABIE-OLIFANTS
}

\section{IRRIGATION SCHEME ।}

Edwan P. Lahiff

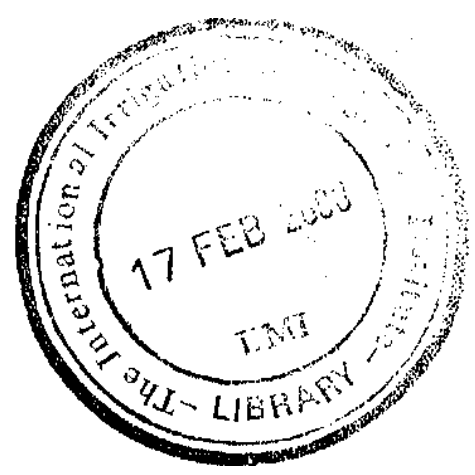

NKL_., DEVELOPMENT ASSOCIATION

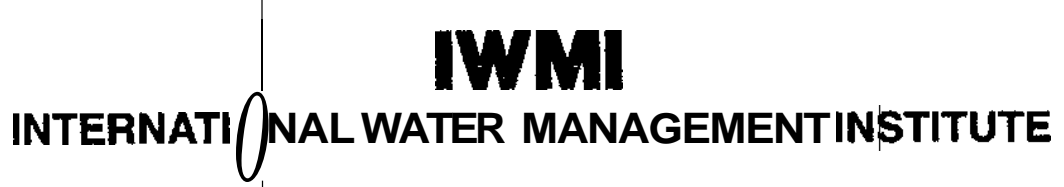

H 25318

c 2 
Lahiff, E. P. 1999. Land tenure on the Arabie-Olifants irrigation Scheme.Colombo, Sri Lanka: International Water Management Institute (IWMI). viii, 51p. (South Africa working paper no.2).

This study, was made possible with the support of the Department for International Development (DFID). reference NRE 9800 605/966/001A.

The International Water Management Institute (IWMI). Colombo, Sril Lanka commissioned this study. The author wishes to thank Drs. Douglas Merry, Herbert Blank, and Barbara van Koppen of the IWMI for their support.

He also thanks the farmers, officials, and community representatives who cooperated with this study and who were so generous with their time. Bettina Hedden-Dunkhorst and the team at the University of the North provided valuable assistance, and Marna de Lange and the Northern Province Department of Agriculture, Land and Environment provided the map of the Arabie-Oififants scheme,

Thabo Malobane, Mmasaku Claudia Mohale, and Teresa Yates; and the author conducted fieldwork for this study.

water resources management / irrigation programs / land tenure / land reform / social conditions / agriculture / rural development / agrarian reform / women / gender / \$outh Africa

ISBN: $92-9090 * 388-0$

IWMI's Working Papers are intended to stimulate discussion amang people interested in aspects of Irrigation management. These papers make available the results of recent or ongoing research, and the informed opinions of IWMI staff members and collaborators, as early as possible. The views expressed are, therefore, those of the author/s and do not (at this stage) necessarily represent the consensus of IWMI or its partners. IWMI will welcome comments on this paper, which should be sent either to IWMI ar to the authors at the following address:

Communications Office

International Water Management Institute

P. O. Box 2075

Colombo

Sri Lanka

(C) IWMI, 1999

All rights reserved.

The International Irrigation Managemen Institute, one of sixteen centers supported by the Consultative Group on International Agricultural Researct (CGIAR), was incorpottated by an Act of Parliament in Sri Lanka. The Act is currently under amendmen to read as International Water Management Institute (IWMI). 


\section{Contents}

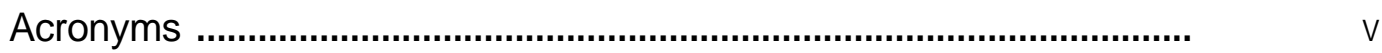

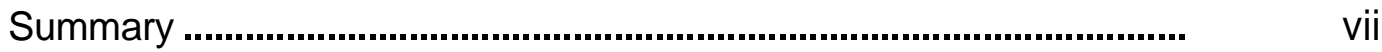

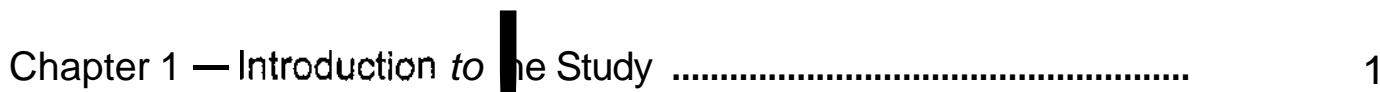

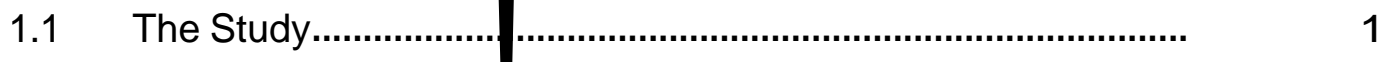

1.2 The Tenure Debate i South Africa .............................................

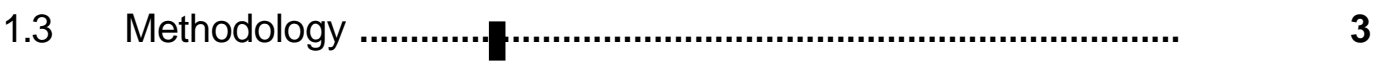

Chapter 2 - South Africa's Agrarian Question .........................................

$2.1 \quad$ Historical Background ............................................................

2.2 Land in the Homelands ..........................................................

2.3 Land Tenure in the Homelands .............................................. 10

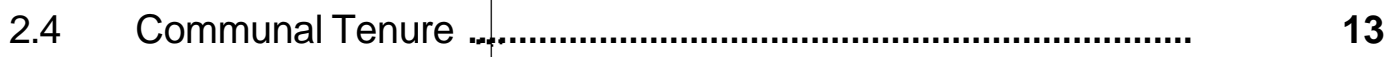

2.5 Agriculture and Rural Development in the Homelands .................... 14

Chapter 3 - Land Tenure op the Arabie-Olifants Scheme ......................... 17

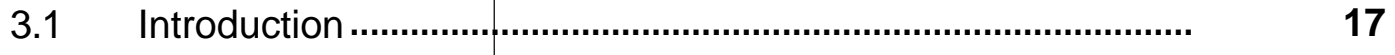

3.2 Land History ....................................................................... 17

3.3 Official Land Allocation and Tenure System .................................. 21

3.4 Popular Perceptions of Land Allocation ....................................... 24

3.5 Changes Affecting $\mathrm{L}$ : ndholding since the Beginning of the Scheme 29

Chapter 4 - Land Tenure eform: Now and in the Future ......................... 33

4.1 Arguments for Tenure Reform................................................ 33

4.2 Options for Tenure Reform under Current Legislation .................... $\quad 35$

4.3 Proposed Changes to Government Tenure Policy.......................... $\quad 37$

4.4 Conclusions ......................................................................... 38

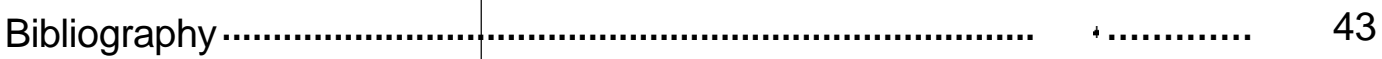




\section{Acronyms}

ANC

ARDC

CPA

DBSA

DLA

IPILRA

|WMI

PTO

$\mathrm{R}$

SADT

SAIRR

SANT

TLC
African National Congress

Agricultural and Rural Development Corporation

Communal Property Association

Development Bank of Southern Africa

Department of Land Affairs

Interim Protection of Informal Land Rights Act

InternationalWater Management Institute

Permission to Occupy

Rand (South African unit of currency)

South African Development Trust

South African Institute of Race Relations

South African Native Trust

Transitional Local Council 


\section{Summary}

This report provides an overview of land tenure and women's access to land on the Arabie-Olifants irrigation scheme, situated in South Africa's Northern Province. It is based on fieldwork and a documentary study carried out in March-May 1999 on behalf of the International Water Management Institute.

The land that makes up the Arabie-Olifants irrigation scheme forms part of the former 'homeland' of Lebowa, an area set aside for exclusively black (African) occupation under the racist system of apartheid. Land was purchased by the state from white owners in the years sipce 1936 and allocated in trust to various communities, or tribes, living under their respective chiefs and village heads. This so-called communal land is used for mixed farming and residential purposes. Over the past four decades, the irrigation scheme has fallen under the control of various state bodies but is now in a state of decline due to cuts in state support.

The chiefs and tribal authorities allocate irrigation plots, usually to male household heads. Plot holders were, up to the legislative changes of 1991 , issued with Permission to Occupy (PTO) certificates by the local magistrate, which \$ranted exclusive life-time usufructuary rights to the land but did not allow for sale, mortgage, lease, or subdivision. While this permit-based system falls far short of private ownership, it would appear to be a relatively secure form of tenure, as most households have been able to hold onto their plots since the inception of the scheme.

Women face multiple forms of discrimination within this tradition-bound society but are able, nonetheless, to gaih access to land under a variety of conditions. While most irrigated plots are registered in the names of men, there is a growing trend towards registering them in the name of actual land users, the great majority of whom are women. As most of the tribal authorities do not encourage women to apply for land in their own name, most are obliged to acquire land through husbands or other male relatives, which leaves them with less secure rights than their male counterparts. Both women and men may inherit land but land does not automatically pass to a widow in the event of the death of a male plot holder. In recent years, many women have acquired 


\section{Chapter 1}

\section{Introduction to the Study}

\subsection{The Study}

This study was commissioned by the International Water Management Institute (IWMI) as part of its 'Water for People' Progam in South Africa. It forms part of the small-scale irrigation component of a wider research program in the Middleveld region of the Olifants river basin, with particularfocus on the Arabie- $\phi$ lifants irrigation scheme. The study' site is located approximately 20 kilometers south of Lebowakgomo in the former homeland of Lebowa, now part of the Northern Province.

The aims of the study, as set out in the project proposal, were to provide a clear analysis of the conditions governing both access to land and land tenure arrangements, on smallholder irrigation schemes in the Olifants river basin, with particular reference to the position of women, and to present recommendations for the reform of land administration practices in the area, with a view to improving access to land for historically disadvantaged social groups, promoting security of tenure, and encouraging more productive use of soil and water resources.

This chapter provides an introduction to the study and a brief outline of the research methods employed. Chapter 2 provides a historicaloverview of lan ${ }^{d}$ tenure in South Africa, with particular reference to the pos tion of African people under apartl $\left.\right|^{1}$ id. Chapter 3 presents the detailed findings of fieldwork carried out on the Arabie-Olifants scheme. Chapter 4 presents a summary of the findings and a discussion of the options for fenure reform under current government policies and proposed new legislation. The bibliography lists all the works cited in the text along with a selection of other relevant material.

\subsection{The Tenure Debate in South Africa}

The debate around tenure reform in South Africa is not a new one. Indeed, it has long been a central feature of the wider debates on access to land by African people under colonialism, segregation, apartheid, and, of late, democracy. This debate has bitted social and economic reformers of various hues against successive governments, with p Plitical expediency generally gaining the upper hand. Notably absent from this debate has be $n$ the voice of rural African people themselves. When runal people have briefly stepped on the stage of history-as happened in Venda in 1940 and in Pondoland in 1960-it has la ely been in an attempt to 
preserve existing ('traditional') systems of land use and administration rather than in pursuit of radical change.

Today, as in the past, the debate centers on individual versus collective control of land, and on western versus African concepts of property. As early a\$1905, the South African Native Affairs Commission had this to say:

Recognising the attachment of the Natives to the present advantages of their own communal or tribal system of land tenure, the Commission does not advise any general compulsory measure of sub-division and individual holding of the lands now set apart for their occupation; but recommends that movement in that directions be encouraged, and that, where the Natives exhibit in sufficient numbers a desire to secure and a capacity to hold and enjoy individual rights to arable plots and residential sites on such land, provision should be made accordingly under well-defined conditions.... (Davenportand Hunt 1974:40).

In similar vein, the Native Economic Cornmission of 1932 (Union of South Africa 1932:23) observed that:

The granting of a title $d \epsilon e d$ and the beaconing off of plots are not enough to secure economic progress ... if productic $n$ is to be increased, holdings must be consolidated rather than further subdivided, and unrestricte $d$ grazing rights on communal land must go.

By mid-century, the Tomlinsor Commission (Union of South Africa 1955:151) reached the by-now-familiar conclusion:

A revision of the systems of te nd tenure is regarded as one of the prerequisites to the stabalisation of the land in the Bantu Areas and the full economic development of their potential ... The Commission recommends the tin areas where the Bantu desire that their land should be granted to them under title deed, this should be done and the existing forms of tenure should be superseded by such grants ... The k rinciple of 'one-man-onetlot' ... reduces every Bantu to a low level of uniformity with no prosf ects of expanding his activities nor of exercising his initiative. It is essential to make opportu nities for the creation! of a class of contented full-time Bantu farmers with holdings of sufficient size to enable them to farm profitably and to exercise their initiative and to develop according tc their individual ability: and resources. 
Offensive language aside, such sentiments will be familiar to 'anyone engaged in current debates around land reform in South Africa (see Cross and Haines 1988; Levin and Weiner 1997). While the general thrust of this debate is towards the neec for more individually based forms of landholding (e.g., freehold), Cousins (1996:173) and the Department of Land Affairs (1997), amongst others, stress the benefits of the communal system, especially communal grazing, in terms of social equity and environmental management.

\subsection{Methodology}

This study represents an attenpt to capture the range of factors that makes up the prevailing land tenure system in one forner 'homeland' area in South Africa's Northern Province. Like most socio-legal systems, the system of land tenure in South Africa's homelands combines elements of formal law. as represented by various statutes, | proclamations and official procedures, and customary practice. What is perhaps unusual about the South African case is that the formal legal aspects are generally unknown or, at best, (poorly understood, by those directly affected by them and, with the transition to democracy, have largely been rendered obsolete.

Three broad research techr iques were employed in the study:

- investigation of the formal legal situation, in historical context, based on a study of official documents and relevan literature;

- empirical analysis of a selection of official records from the Arabie-Olifants scheme and the Deeds Office, Pretolia; and

- interviews with chiefs, members of tribal authorities and transitional local councils (TLCs), government officials, farmers' representatives, and individual plot holders on the Arabie-Olifants scheme

Preparatory work began in February, 1999. and fieldwork was conducted from March to May, 1999. In all, 14 visits we-e made to the Arabie-Olifants scheme and surrounding areas, and altogether 20 interviews were conducted with groups and individuals.

For the purposes of this study, the Arabie-Olifants scheme is defined as the fourteen farms lying along the right (southeastern) bank of the Olifants river, stretching from Hindostan to Mooiplaats. Brief reference is also made to the Sepitsi scheme, on the left bank of this river. 
The available resources did not allow for a widespread survey, so interviews were all semistructured, based on a variable list of key questions. The broad issues explored in all these interviews were:

- How do people gain access to land?

- Who may hold land?

- What security of tenure do landholders enjoy?

- Are changes in either the current system of tenure or allocation required?

Needless to say, the precise form of questioning varied considerably depending on the informant, as did the answers obtained. The information obtained was largely qualitative in nature and presented man challenges at the analysis stage. The presentation of the research findings in the following chapters takes a largely discursive approach, which attempts to expose and comment on the range of opinions obtained without imposing unsustainable certainties on what remains an extremely fluid and subjective area of knowledge. 


\section{Chapter 2}

\section{South Africa's Agrarian Question}

\subsection{Historical Background}

The formal ending of apartheid, and the coming to power of the country's first democratically elected government in April 1994, raised the possibility of fundamental social and economic changes in South Africa. The nature of the negotiated end to white minority rule has, however, left much of the structure of racial inequality intact, particularly!in areas such as income, landholding, and access to health, education, and welfare services.

Of all the manifestations of inequality and oppression under apartheid, none was as stark, or potentially as enduring, as the territorial separation of peosle along racial lines. The establishment of separate rural homelands for the African populaton was central to the aims of the 'grand apartheid' and an essential component of the system of economic exploitation and political repression, which sustained the power and wealth of the white minority.

The roots of territorial segregation are found in the uneven patt 9 tn of colonial dispossession and settler occupation in the nineteenth century. Sizeable tracts of land-mainly in the eastern half of what became South Africa-continued to be occupied by native peoples, defeated but not entirely subdued, with much of their preexisting sociopolitical ${ }^{\text {and }}$ economic system intact (Welsh 197129; Thompson 1995:109).

With the rise of a vast mining industry in the late nineteenth century, these 'native reserves' took on a new significance as reservoirs of migrant labor. The racial order that had characterizedthe preindustrial settler society found new expression in highly repressive o o $\mathrm{s}$ of labor organization on the mines. This was based on a tightly regulated system of oscillating migration by male African workers between the mines and the rural periphery, and the systematic suppression of black political rights (Dubow 1989:39; Crish, Jeeves, and Yudelman 1991:2).

The 'native reserves' were central to the policy of segregation, both as a rural base for migrant workers and as places where the African population could be controlled under a separate legal and administrative system. The reserves were defined by two key pieces of legislation, the so-called Land Acts of 1913 and 1936, which between them divided the country into legally designated 'white' and 'black' territories and imposed severe restrictions on the property rights of blacks, especially the so-called squatters (tenants and sharecroppers) on 
white farms. Despite their repeal in 1991, the division of territory along racial lines imposed under these acts effectively defines the pattern of landholding in rural South Africa to this day.

Under the terms of the 1913 Natives' Land Act, 7 peraent of the national territory was reserved for exclusive black occupation and Africans were prohibited from acquiring land outside these 'scheduled' areas. For Bundy (1979:213), this 'freezing' of African landholding was intended to inhibit the process of class differentiation within the reserves and prevent the emergence of either a class of black commercial farmers or a landless proletariat, each of which posed its own threat to the system of racial segregation and migrant labor. The 1913 Act also attempted to abolish the widespread practice of sharecropping by black 'squatters' on white-owned farms, particularly in the Orange Free State, and other forms of tenancy that did not involve at least 90 days of compulsory labor service to the landlord.

The 1936 Native Trust and LandAct allowed for the extension of the reserves up to a total of 13 percent of the national territory and created the South African Native Trust (later Development Trust) with responsibility for acquiring the necessary ('released') land. in a reversal of earlier policy, the Trust was also charged with the economic development of the overcrowded and poverty-stricken reserves and preventing what was seen as an imminent economic and ecological crisis (Bundy 1979:222). This led to the highly authoritarian system of 'betterment,' which attempted to prevent soil erosion and control the heads of cattle in the reserves, and in later years it was expanded into a comprehensive system of physical planning and 'villagization' (Yawitch 1981:1; de Wet 1995:40). Like its forerunner, the 1936 Act combined the allocation of lands to the reserves with a further legal assault on black tenant farmers on white farms through its restrictions on labor tenancy (in favor of a system of wage labor), although opposition from tenants, and some farmers, meant that these provision were not fully enforced for 30 years (Morris 1976:334).

The coming to power of the overtly racist National Party in 1948, under the ideological banner of apartheid, marked the beginning of a decisive new phase in the evolution of South Africa's system of racial segregation and in the function of the reserves. Under the system of 'separate development' as it evolved in the years after 1948, and especially under Prime Minister Verwoerd from 1958, Africans were to be denied all political rights in 'white' South Africa, where they would be tolerated only as long as they were deemed to be 'economically useful.' Africans were to be made 'citizens' of eight (later 10) ethnically based 'nations,' situated in the reserves, where they would be encouraged to develop separate political institutions and move towards 'independence.' 
Political power within the homelands rested with revamped 'tri Lal' structures, composed of headmen and chiefs, under the cose control of the Department of Bantu Affairs. The basis of tribal administration in the reserves had been established by the 1927 Native Administration Act, but was greatly extended by the 1\$51 Bantu Authorities Act and the 1959 Promotion of Bantu Self-Government Act, which strengthened the political power of the government-appointed chiefs and created a multitiered system of tribal. regional, and territorial authorities (Hiil 1964:15).

The imposition of tribal rule was accompanied by the extension of a much-expanded form of 'betterment' to most of the reserves/homelands, involving forced resettlement of villages, strict limits on land for cultivation, and furtr er attempts to reduce the numbers of livestock (Yawitch 1981:23). This was met with violent opposition in places such as Sekhukhuneland, in the northern Transvaal, in 1958 and in Pordoland, in the eastern Cape, in 1960 (Mbeki 1984:111).

As the homelands policy began to ta ke effect in the 1960s and 1970s, upwards of 3.5 million 'surplus' people were forcibly removec to the homelands, includin tenants evicted from white farms, residents of church mission slations, and other so-called 'black spots' outside the homelands, and people 'endorsed out' cf towns and cities (Platzky and Walker 1985:9). Millions more, both in the reserves and in 'wh te' South Africa, were stripped of their South African citizenship.

Economically, the homelands rema ned extremely poor and upderdeveloped, and heavily dependent on remittances from migrant workers in industrial South Africa and direct transfers from the Government of South Africa. Tr e communal system of land tenure, under the control of the tribal authorities, meant, at least unti the 1970 s, that most households in the homelands had some access to arable or grazing land but the small size of plots and herds meant that agriculture contributed a relatively minor proportion of household subsistence requirements in most cases (Simkins 1981:262).

By the final years of apartheid, the hc melands were home to over half the black population of South Africa (or over $40 \%$ of the entire South African population] and were characterized by extremely low incomes and high rates of infant mortality, malnutrtion, and illiteracy relative to the rest of the country (Wilson and Ramp hele 1989.25; DBSA 1993:37). Indeed, the available evidence suggests that South Africa contir ues to have one of the most unequal distributions of income in the world, and income and mate rial quality of life are strongly correlated with race, location, and gender. Whiteford and Mcc rath (1994:59) estimate that 67 percent of black households, heavly concentrated in the form er homelands, are living below the official poverty 
line; of these, households headed by women are substantially worse off than those headed by men.

\subsection{Land in the Homelands}

Of a total South African land area of 122 million hectares! (1.2 million square kilometres), approximately 16.7 million hectares, or 13.7 percent, was allocated to the homelands in 1985 (Nattrass 1988:99). Within this area, the population was estimated at 17.4 million people in 1991, or 47 percent of the South African population (SAIRR 1994:83). Approximately 99.8 percent of this group were classified as black (African), as compared to 46 percent of the non-homelandpopulation.

Conventional wisdom for many years held that the homelands, concentrated as they were in the wetter, eastern portion of South Africa, contained a favqrable proportion of good quality arable land (Union of South Africa 1955:47; Houghton 1973:80). This view has been challenged by such authors as Levin and Weiner (1991:92) and van Zyl and van Rooyen (1991:184), who suggest that as much as $\mathbf{1 5 . 6}$ percent of non-homeland land is arable, compared to only 11.8 percent of the homelands. This wouid give the homelands just 11.1 percent of South Africa's arable land once factors such as rainfall, slope, and soil are taken into account. Moreover, the quality of land in the two areas may not be comparable: 65 percent of arable land outside the homelands is considered to be 'of medium to high potential' (mainly concentrated in Natal and the eastern Transvaal), compared to only 50 percent within the homelands (van Zyl and van Rooyen 1991:184).

Since the 1950s, all the available sources point to a dramatic fall in the size of average landholding and an increase in the proportion of landless households. Between 1970 and 1985, the population of the homelands at least doubled (from around 7 million to 14 million people), with no more than a marginal increase in land area (under 10\%) (Steenkamp 1989:15). Natural population increase, forced removals from 'white' areas, and the redrawing of homeland boundaries to include a number of densely populated areas, meant that the proportion of the black population officially domiciled in the homelands increased from 39.1 percent in 1960 to 52.7 percent in 1980 (Platzky and Walker 1985:18). Recent estimates suggest that the total arable land in the homelands is only sufficient to provide leach household (averaging six persons) with approximately one hectare (Cobbett 1987:66; Tapson 1990:566). but this figure varies considerably between homelands, ranging from 0.2 hectare per household in QwaQwa to 1.5 hectares in Transkei. 
Obviously, these figures fepresent only the potential distribution, whereas in fact, a considerable number of households are known to be landless or near landless. While no precise figures are available for andlessness in the homelands, estimates of 40-50 percent of households are commonly cited (Bembridge 1990.18; Levin and Weiner 1991:92), with major differences within and between the homelands. Cooper (1988:95) puts the proportion of landless households in the most densely populated homelands, QwaQwa and KwaNdebele, as high as four out of five.

Detailed information on landholding within the homelands is extremely limited. Official statistics tend to be compiled from a variety of local studies and from estimates prepared by homeland governments, with considerable variation in quality and reliability. Many people with rights to arable land are not using their lands, many people are cultivating lands to which they have no formal rights, and a substantial amount of cultivation tak»s place on people's house stands, all of which adds to the difficulty of quantifying landholding1in the homelands with any accuracy.

In Lebowa, Vink (1986a:102) finds that 45.6 percent of households in the rural areas surveyed had rights to arable land, and a further 20 percent had access to grazing land only, but says that only one third of those with grazing rights was actually availing of them. Also in Lebowa, Baber (1996:288) found that 72 percent of households in the long-established village of Mamone had their own arable land but in the more recent settlement of Rantlekane only 45 percent of households had land. Work by Weiner, Chimere-Dan, and Levin (1994:30) in four areas of the Central Lowveld (covering parts of KaNgwane, Gazankulu, and Lebowa) found that a quarter (24.5 percent) of households in the study had access to| agricultural land but, when cultivated land adjacent to homesteads ('gardens') was included, this figure rose to 62.3 percent. Of the households with land, over 80 percent cultivated areas greater than 0.1 hectare, and the average area available for cultivation was 0.9 hectare per household. There was, however, considerable variation within the study area, with average holdings ranging from $\mathbf{0 . 4}$ hectare in Marite village (Mapulaneng, Lebowa) to 2.8 hectares in Cork village (Mhala. Gazankulu). Values from the Development Bank of Southern Africa (DBSA 1993:105) suggest that more than 50 percent of rural households in Gazankulu are without land but the rate varies from 85 percent in Ritavi Magisterial district to 17 percent in Giyani. 'The same source estimates landlessness in the homelands. of Venda at $\mathbf{3 6}$ percent of households and of Lebowa above $\mathbf{5 0}$ percent of households.

While a certain amount can be said about arable land, very little) is known about the system governing access to grazing land in the homelands. It would appear that people with grazing 
rights are, by and large, those with arable rights, although not every household with grazing rights actually keeps livestock, and many without formal rights do so. Data presented by Weiner, Chimere-Dan, and Levin (1994:30) for areas as disparate as the Transvaal Central Lowveld, KwaMakhanya in KwaZulu, and Herschel in Transkei, suggest that households with access to grazing land number less than half of those with access to arable land, although no explanation for this is provided. While pastures are generally used communally, examples have been found of chiefs and others fencing off land for their private use.

To summarize, the general pattern that emerges from the literature suggests that arable land in the homelands is distributed between a relatively 'large proportion of' households; perhaps as high as 50 percent, but average holdings are extremely small, ranging from 0.5 hectare to 1.5 hectares per household. There is, however, considerable variation in plot sizes, with a substantial proportion of households having less than half a hectare, and a small 'elite' having plots larger than 5 hectares. There is also considerable variation between regions and districts. In 'deep rural' parts of Transkei, KwaZulu, and Venda, virtually every household has access to land for agricultural purposes, whereas in many;'closer settlements' virtually no residents have rights to land other than residential plots, andin many areas even these rights are not well established.

\subsection{Land Tenure in the Homelands}

The pattern and forms of landholding and land use in the homelands have been directly influenced by the policies and actions of the South African State (in its various forms) in pursuit of racial segregation and the promotion of an oppressive migrant labor system. State policy on land in the reserves/homelands since 1948 has been based on a number of key elements. described by Hendricks (1990:162) as the 'three rural pillars of apartheid' - namely the so-called communal form of tenure, the system of tribal administration (the chieftaincy), and various forms of rural planining and developrnent, generally referred to as 'betterment.' To these may be added a fourth important element-the forced removal of millions of black people from 'white' farms and towns to the reserves/homelands, which began in earnest in the Free State with the Natives Land Act of 1913, and which accelerated dramtatically throughout the country in the 1960 s and 1970s.

The roots of the forms of tenure found in areas such as the former Lebowa can be traced back at least as far as the mid-nineteenth century. The settler government of the Transvaal as early as 1855 (Resolution 159) precluded anybody who was not a 'burgher' from owning land in the Transvaal while simultaneously precluding 'natives' from burgher rights. Following the first 
Anglo-Boer War, the Pretoria Convention of 1881 (Article XIII) laid down that 'Natives will be allowed to acquire land, but the grant or transfer of such land will in every case be made to, and registered in the name of, the Native Commission' (quoted in Davenport and Hunt 1974:40). For only a brief period, between 1905 and 1913, Africans in the Transvaal were allowed to acquire land in their own names. Since that date, African people in the Transvaal (and elsewhere in South Africa), continue, with the exception of certain urban areas, to live under a variety of tenure systems that deny them full rights of landownership.

The greater portion of land in the former homelands is held under some form of communal tenure. Other tenurial forms include freehold land held by individuals and groups, including church missions and state land, but these account for relatively small areas. Communal land tenure in South Africa is a hybrid form, specific to the homelands, Which combines elements of individual and collective property rights. Although having some başis in African customary law, communal tenure has been greatly modified by successive governments over the course of the twentieth century, while alternative forms of landholding were effectively denied to black people by law. Authors such as Lacey (1981), Haines and Cross (1988) and Hendricks (1990) argue that communal tenure was an essential component of the migrant/labor system, facilitating the concentration of the maximum possible number of Africans in the reserves/homelands, preventing the emergence of a stratum of rich peasants or capitalist farmers, and providing the basis for a high degree of social control through the tribal leaders who controlled access to land.

Legally, most communal land (with the exception of 'bought farms') is nominally owned by the state, but is held in trust for specific tribal communities and allocated by the chiefs to people living under their jurisdiction on a usufructuary basis (Budlender and Latsky 1991:121). In popular perceptions, virtually all categories of land in the homelanids are believed to belong to the community, or the chief (whether in a moral or a legal sense)| despite the fact that formal titles (in the form of deeds) are, in most cases, held by the state.

Land administered under the communal system can be divided into three broad categories, although the differences (at the level of law and popular perceptions) are often blurred. At the heart of most of the homelands lies land that is generally referreld to as 'tribal land' (or tribal farms). This is land that had been occupied by tribes prior to 1936| and, in many cases, without interruption since precolonial tmes. Nominal ownership to most of this land was appropriated by the state at various times prio to 1936 , but this was not generally laccompanied by any change in occupation or land use and often went unnoticed by the inhabitahts This land makes up most of the land 'scheduled' for black occupation under the 1913 Land Act. Nominal ownership of this land was passed to the South African Native Trust in 1936, but again this brought little or no 
immediate change to the inhabitants. The 'reforms' introduced by the Trust after 1936 were mainly focused on newly acquired land (Trust farms), with the result that the older tribal farms have relatively greater continuity of occupation and social structure.

From 1936 onwards, the South African Native Trust (later, and somewhat euphemistically, the South African Development Trust, or SADT) set about purchasing thousands of farms for addition to the then native reserves. This land was generally allocated for the use of specific 'tribal communities' and, according to the 1936 Act, was held initrust by the State President (or officials appointed by the President). The Trust also set about buying-up much of the privately owned land within the enlarged reserves, including mission land $\$$ and lands belonging to whites. In addition, the Trust acquired nominal ownership to state land earmarked for inclusion in the homelands (released areas) and all tribal farms (scheduled areas) that were not in private ownership.

The third category of land that constitutes today's black areas is privately owned land, typically land that was bought in undivided shares by groups pf named black farmers. Such purchases were made in the scheduled areas prior to 1913, outside the scheduled areas from 1905 to 1936, and from the Trust after 1936 (Vink 1986b:33). While some groups were successful in having title deeds issued in their own names, others were obliged by the racial laws of the day to register the land in the nama of a tribe or state official, to be held in trust for the named purchasers. Over time, the sense of private ownership would appear to have faded (if indeed it ever existed) and today, most such land is used and administered by communities (or chiefs) in a way that is indistinguishable from other communal land.

As suggested above, popular perceptions of landownership do not tend to correspond fully with the official legal position. On tribal farms, the sense of community ownership is probably the strongest, based on uninterrupted occupation, strong historigal claims, and a relative lack of state interference over the years. These are the bastions of chieffy power and there is little or no awareness of (and certainly no sympathy for) the position of the state as nominal owner of the land. On Trust farms perceptions are somewhat different, as there is generally a greater awareness of the state as nominal owner even though many pepple believe that the permission given to the community by the state to occupy the land is tantamount to a transfer of ownership. The small number of farms bought outright by tribal groups or other communities constitute a separate category of full (individual or collective) private owner\$hip, with no state involvement, but in practice, popular perdeptions do not differ greatly between|the three categories. In a study of the communal land system in the Transkei, Solinjani (1986) found that "most informants believed that the land belonged to the tribe and that the chief ... had authority over all the people 
and all the land." Here we see a good example of the conflation of property rights and sociopolitical jurisdiction that characterizes much of the debate around land and traditional leaders in South Africa. The minority that differed from this view, according to Solinjani, believed that the land belonged to the government and was under the control of the magistrate, as it was he who issued Permissionto Occupy (PTO) certificates.

\subsection{CommunalTenure}

The communal tenure system found in South Africa is 'communal' in the sense that an individual's entitlement to land flows from membership of a sociopolitical community (a village or tribe), rather than from private ownership (Bennett 1995:168). Communal tenure, in the South African context, does not imply communal (or collective) agricultural production, even on shared resources such as cornmunal grazing land. Nor does it imply that the entire community makes all decisions regarding the allocation of land. Examples of collective production may be found, such as exchanges of labor or plowing cattle, or joint production of vegetables or poultry on small income-generatirg projects, but these constitute the exception' rather that the rule, and are largely independent of the land tenure system.

Land for arable and residential purposes is usually obtained through the tribal chief or, more commonly, the village headman acting on behalf of the chief, who may allocate plots from whatever land is currently available. Solinjani's (1986:2) study from the Transkei provides a rare description of the role of village headmen in the allocation process, a process which, with minor local variations, applies throughout much of the country: "The local headman was seen as acting for the chief and the most senior chief. An applicant was; expected to approach the headman through his own sub-headman. Thus, applying for land involved one consulting his family, the sub-headman, and the headman. The headman had to be given a gift in the form of liquor plus cash which varied from place to place."

Under customary law, the right to land usually applies only to male 'household heads,' but in practice, it is sometimes extended to women (Bennett 1995170). For Solinjani, referring to the Transkei, "Anyone who was married and was a permanent resident of any of the areas under (the chief's) jurisdiction was qualified to apply for land. In addition1 all unmarried females who had children could also apply for land if they were permanently resident." This combination of requirements-membership of the community and head of a household-together with some discrimination between men and women, recurs throughout the homeland areas, with minor local variations. 
Once allocated, residential and arable plots are reserved for the exclusive use of the occupying household. Unallocated lands are generally available to community members as a common pool resource (commonage), providing pasture for livestock and other natural resources such as timber, thatching grass, edible fruits and plants, and materials for use in traditional medicine (Cousins 1996:168). Those who obtain land receive a right to the permanent use and benefits of that land, but have no right to sell it and can only transfer it to another family member with permission of the tribal leaders. Chiefs and tribal authorities have, in principle, the power to repossess land if it is abandoned; iff it is needed for another purpose such as a road or a public building; if it is deemed surplus to the needs of the holders; or if it is to punish a landholder for some offence. Examples of such repossession are rare, however, and the communal system is generally seen as a reasonably secure form of tenure (Bromberger 1988:208).

In addition to the Land Acts, the principal legal instruments governing access and use of South African Development Trust Land were (using their original titles):

- The Control of Irrigation Schemes in Bantu Areas (Proclamation $\boldsymbol{R} 5$ of 1963) which consolidated regulations controlling irrigation schemes in Black Areas.

- The Trust Forest Regulations (Proclamation R 191 of 1967), which regulated the use of forest land in Black Areas.

- The Bantu Areas Land Regulations (Proclamation 188 of 1969), which regulated the tenure in all South African Development Trust areas.

All of these were proclaimed under the authority of the Native Administration Act, 1927 (Act No. 38 of 1927) and the Native Trust and LandAct, 1936 (Act No. 180f 1936).

Prior to the legislative reforms and the virtual collapse of the homeland administrations in the early 1990 s, occupant $\$$ of communal land could register their residential and arable holdings with the local tribal authority and magistrate's office, where they would be officially granted 'Permission to Occupy,' either verbally or in writing. This system was not observed in all cases and, since the abolition of all 'racially based' land laws in 19\$1, the legal situation is far from clear (Cross and Rutsch 1995:23; Westaway 1995:11).

\subsection{Agriculture and Rural Development in the Homelands}

Since the creation of the African reserves in the late nineteenth and early twentieth centuries, most of their inhabitants have been able to obtain only a part of their livelihood from agriculture, 
and throughout the twentieth century, commentators have warned of the imminent collapse of the agriculture sector in the homelands.

In the wake of the Tomlinson Commission's Report (Union of South African 1955), some efforts were exerted to develop smallholder agriculture, including an expansion of the area under irrigation. but government policy towards the reserves was still largely concerned with 'betterment.' Efforts were also exerted to establish a small elite of 'commercial' farmers on 'economic' holdings, mainly on land acquired by the Native Trust, who became the main beneficiaries of the homeland agricultural policy in the 1970s and 1980s (Watkinson 1996:48).

From the mid-1970s, agricultural policy in the homelands began to focus on the development of a range of large-scale agricultural projects, mainly under the control of newly created parastatal (semi-state) organizations but in collaboration with private-sector investors. Most were highly inefficient and were in decline by the late 1980s, but they did create some opportunities for 'accumulation from above' by a small elite allied to the homeland governments (Cooper 1991:253). Today, agriculture in the homelands is commonly perceived as 'subsistence' (or even 'sub-subsistence')-oriented and extremely marginal compared to the white-dominated agriculture sector. Local studies over many year\$, however, have shown that agriculture continues to play a significant part in the livelihoods of large numbers of households. Bernstein (1996:38) argues that far from being homogeneous, the agriculture sector in the former homelands is highly differentiated along lines of class, gẹnder, and generation (age), with substantial numbers of farmers producing for formal and informal markets.

The general impression of homeland agriculture that emerges from the literature is of a sector overwhelmingly composed of very small-scale farmers, producing mainly food crops for direct consumption, under conditions that are relatively underdeveloped in terms of methods, materials, and integration into formal markets (see Lahiff 1997a). The available evidence suggests that while agriculture is not the principal source of livelihood for the great majority of households in the homelands it does provide an important supplementary income for a substantial proportion, albeit with a high degree of differentiation between households. Access to land, even relatively small plots or a share of communal grazing, allows households to maintain a diversified livelihbod strategy that may include wage employment, pensions, agricultural production (for consumption or sale), and the keeping of livestock as a form of investment, which together enhance their ability to obtain a livelihood under difficult conditions. 


\section{Chapter 3}

\section{Land Tenure on the Arabie-Olifants Scheme}

\section{1 introduction}

This section provides a brief description of the Arabie-Olifants $\mid$ scheme (figure 1) and an introduction to the main land tenure issues identified during the research.

The Arabie-Olifants irrigation scheme is located in the former 'homeland' of Lebowa, now part of South Africa's Northern|Province. The irrigated lands lie on the right (southern) bank of the Olifants river, at approximately $24.08 \mathrm{~S} 32.39 \mathrm{~S}$. The overall scheme is Icosely structured, in that it does not share a common infrastructure or central management. Water is drawn directly from the Olifants river, from the Arabie dam (upstream of the scheme) and frc $m$ tributaries of the Olifants river. The irrigated land, whose total area is approximately 2,223 heclares, is located on 14 farms. ${ }^{1}$ There are an estimated 1,650 plots, ranging in size from less than 1 hectare to 5 hectares. Flood irrigation, furrow irrigation, sprinklers, and central pivot irrigetion are all in use on the scheme. State and parastatal agencies provide irrigation management and farmer support services but, since 1996, they have been in severe decline, leading $r$ any plot holders to suspend or abandon agricultural activities. The technical and economic aspects of the scheme are not dealt with in any detail by this study. ${ }^{2}$

\subsection{Land History}

The land that comprises the Arabie-Olifants scheme is highly suited to irrigated agriculture, and has been so used since at least the beginning of this century. Official land registry records show that this land was first surveyed and allocated to private owners by the Government of the Transvaal during the period 1871 to 1873 . This was a time of steac $y$ encroachment by white settlers into the land of the native Pedi people under their great chief Sekhukhune, prior to their defeat and subjugation by British-led forces in 1879 .

\footnotetext{
'The term 'farm,' in the South African context, has a meaning that goes beyond the normal usage in the agricultural literature. It refers to an original land grant, whict has been surveyed and recorded in the deeds registry and topo-cadastral maps. Thus, in the case of the Arabie-Olifants scheme, it indicates a property (or administrative) unit rather than an agricultural enterprise.

${ }^{2}$ See related reports, such as that by Mpahlele, Malakalaka, and Hedden-[ unkhorst (1999) for detailed treatment of these topics.
} 


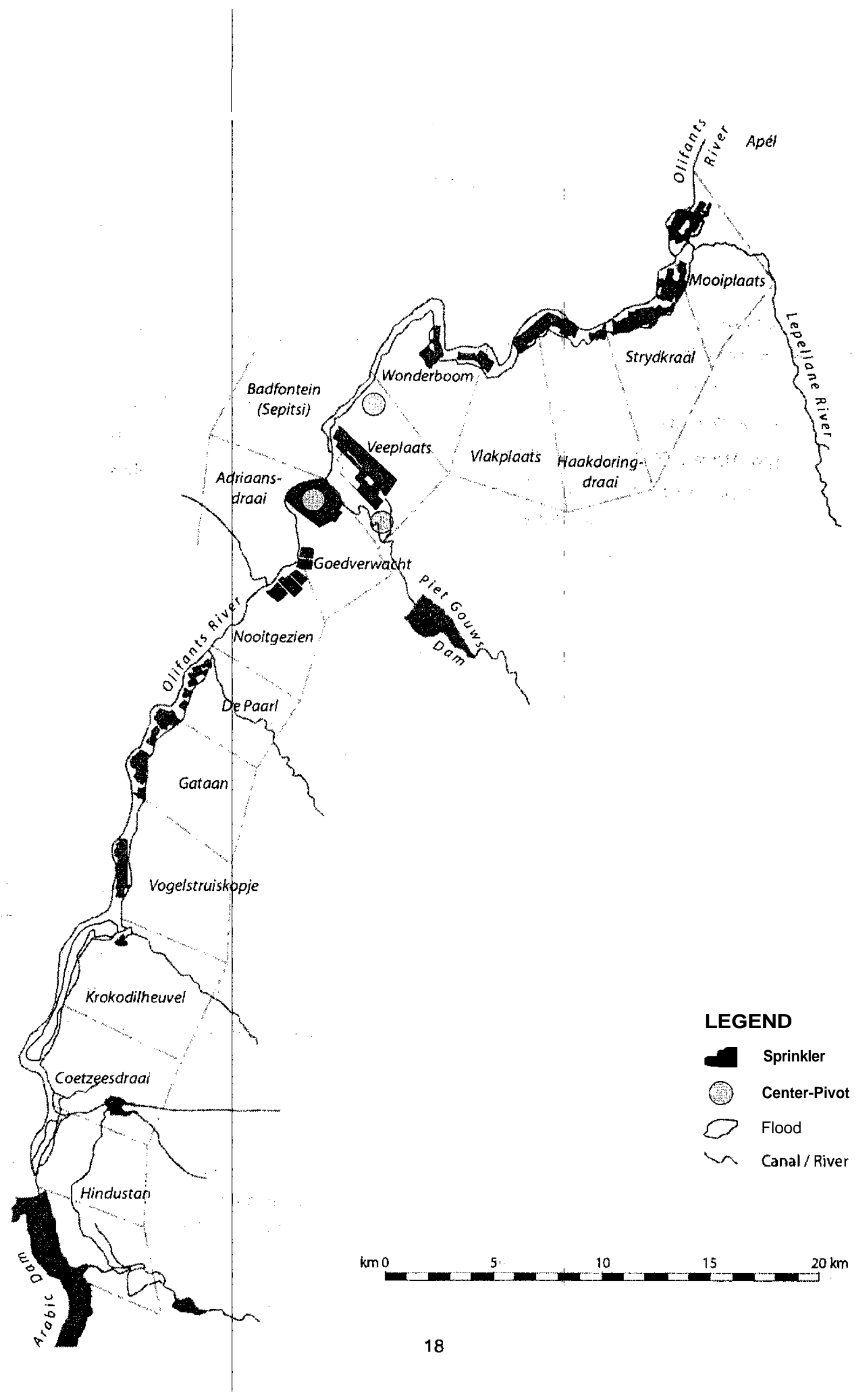


The earliest deeds (referned to as an Original Deed of Grant) issued on the farms in question were to the farms Gataan and Vogelstruiskopje, issued on 4 March, 1871, and the latest was to the farm De Paarl, issued on 22 December, 1873. An examination of the original documents in the Pretoria Deeds Office revealed that all the farms were granted to separate individuals (as opposed to companies), all with Afrikaner or English surnames. This is in line with the pattern of conquest and expropriation throughout southern Africa during the eighteenth and nineteenth centuries, whereby the settler-colonialistssurveyed and granted property rights to white people without reference to the preexisting rights (and occupancy) of African peoples. Although no firm evidence could be found as part of this study, the likelihood is that these farms were acquired by their new white owners complete with resident populations of Africans, who would have been coerced into providing free labor to the emerging landowning class (see Dellus 1983:129).

Over the 60 or 70 years that followed the original deed of grant, all of these farms changed hands at least once, and some as much as five times, as a result of inheritance, sale, and bankruptcy. The farm Strydkraal, for example, was originally granted to a J.B. Brown in 1872, who sold it to the Oriental (Transvaal) Land \& ExplorationCompany, Ltd. in 1885. United African Lands Ltd. subsequently acquired it, by order of court, in 1910. This company then separated the mineral rights, which it retained for itself, from the surface rights, which it sold to O.T. van Niewkerk in 1920. This pattern, whereby farms were acquired by mineral speculation companies, that separated the mineral rights from the surface rights, was repeated on 12 out of the 14 farms that make up the Arabie-Olifants scheme. By the mid-1930s, all the farms (minus the mineral rights) were back in private hands. Entries on the fitle deeds from this period indicate that the landowners, particularly those on the upper reaches, were paying water levies to the Middleburg Irigation Board, which suggests that irrigation was already established on these farms.

In 1936, after more than 20 years of deliberation, the.Government of South Africa passed the Native Trust and Land Act, which made provision for the purch Pse of land for the purposes of extending the so-called Native Reserves (see chapter 2, abode). Over the 25 years that followed, the South African Native Trust (later Development Trust) purchased the 14 farms that today make up the Arabie-Olifants scheme, starting with the farm Mooiplaats, acquired in 1938, and ending with the farm Godverwacht acquired in 1963. No information could be found regarding the existence of African residents on these farms at the time of purchase by the Trust, but it is likely that at least the former farm workers and/or labor tenants were still there. By the 1950 s and 1960s, however, when the current residents took up occupation, many of these 
farms were empty, which suggests a pattern of forced evictions by the Trust. This hypothesis is; supported by a land claim, which has been lodged with the Commission for Restitution of Land Rights (under the 1994 Restitution of Land Rights Act) by the Phetwane Community on the farm Hindostan. These people, part of the Ga Phahla community and currently residing in the Leeuwfontein township adjacent to Marble Hall, claim that they were forcibly removed by the Native Trust in 1958 for reasons of 'ethnicity,' as the farm waslintended for the Matlala people.

Three of the communities currently inhabiting the Arabie-Olifants farms have been relocated from outside the immediate area. This was part of the processes of 'homeland consolidation" and social engineering that were integral to the policy of Grand Apartheid. The Masha community was moved from an area known as Kalkfontein, in what is now Mpumalanga province, in the 1950s. Members of the Mampana commudity were previously scattered on various white farms and parts of Sekekhuneland and were throught together under their own chief on the farm Krokodilheuvel in 1962. The Matlala community that occupies the farms Hindostan and Coetzeesdraai were moved from Jane Furse. Where they shared land with other tribes, in the 1960s. The Masemola community originated in the areas of the present-day scheme and, although for long they were scattered under various white farmers, they were eventually consolidated into the nine farms at the center of the ischeme.

When the communities now occupying the irrigation scheme were first granted occupation, the land had the status of 'Trust Farms,' in that it was owned by the South African Native Trust (a state body). Farms were allocated for use purposes to four specific communities ('tribes'), each under a chief. Withih a chieftaincy, the population was usually divided into villages, and each farm was for the sole use of one, or occasionally two, villages. The Matlala community was granted two farms on the scheme (as well as other land), Mampana one farm on the scheme, Masemola nine farms on the scheme, and Masha community two (and no other land). The irrigation system itself took many years to develop and not all of the farms had been irrigated when these communities first arrived (see below).

The legal status of these farms has changed somewhat since the Trust first acquired them. From about 1986, the policy of the Government of South Africa was to transfer the ownership of land in the homelands to the homeland governments and, im some cases, to the occupying communities themselves. Thus, we find that the farms Hindostan, Coetzeesdraai. Krokodiheuvel, De Paarl, Gataan, Goedverwacht, Vlakplaats, Strydkraal, and Mooiplaats were transferred to the Government of Lebowa in 1993. The farms Veeplaats and Nooitgezien remain 
registered in the name of the SADT and two farms, Haakdorinsdraal and Vogelstruiskopje, were acquired by the Masemola Tribe, in $1994 .^{3}$

It is unlikely that these changes were intended to affect the way in which land was held by individuals (or households) within those communities, as landholders continued to be subject to the rules of the wider community as before. With the exception of farms transferred to particular tribes, all the land on the scheme can be classified as state land, which has been allocated for use purposes to specific communities, with the formal title retained by the Minister of Land Affairs. Current government policy recognizes and protects the rights of such long-established communities occupying state land, and the Department of Land Affairs was, until recently, in the process of preparing legislation that would allow for the transfer of ownership to democratically constituted community groups, although this process would now appear to be on hold.

\subsection{Official Land Allocation and Tenure System}

Plot holders and officials on the Arabie-Olifants scheme were found to be in broad agreement as to how the plots on the irrigation scheme were originally allocated. The design of the scheme-and hence decisions about the size and number of irrigation plots-would appear to have been carried out by officials of the SANT (SADT), without consultation with the would-be beneficiaries. Most of the farms were intended to be used for both agricultural and residential purposes, and so were divided into distinct zones-irrigated lands (subdivided into individual plots), residential areas (also subdivided into 'stands'), and communal grazing for the use of those with livestock. Given the limited areas allocated for grazing, it would appear likely that restrictions were placed on the numbers of livestock that could be brought onto the farms. Residential stands are generally described as being one-quarter hectare in extent. The irrigated plots demarcated during the 1950 s and 1960 s were generally 1.28 hectares in extent, equivalent to 1.5 morgen, a standard size for plots on SADT irrigation schemes throughout the country at that time. In later years, there was a trend towards larger plot sizes. The precise sizes of plots recorded on the PTO certificates, however, show some variation. On the farms De Paarl and Gataan, for example, where plot sizes were all described by officials as being 1.28 hectares, the sizes shown on the PTOs ranged from 0.83 hectare to 1.28 hectares while on Haakdorinsdraai they varied from 0.75 hectare to 1.25 hectares.

At Krokodilheuvel plot holders reported that, as they arrived on the farm, the local Commissioner allocated housing sites and irrigable plots to them, assisted by their chief. Each household was allocated one residential site and one irrigated plot, and it would appear that no

\footnotetext{
${ }^{3}$ No ownership details could be found for the farm Wonderboom.
} 
household was left without a plot. his neat match of households to plots would suggest some degree of preselection of beneficiaries at the time the community was preparing for relocation, but no information could be obtained on this question. It was suggested on this and other farms that the numbered plots were linked to the numbered residential sites - in other words, the plot a particular household was granted depended on where they were to live, and no deviation from this pattern was allowed. All respondents emphasized that plots were, in the first instance, allocated to 'households' and registered in the name of the household head, usually a man. It 'is not clear whether any female-headed households were amongst those that received land at this time.

It is also not clear what form the original registration of plots' took, but from 1969 onwards, all lands were held on the basis of Permission to Occupy (PTD) certificates, issued under the Bantu Areas Land Regulations (Proclamation R188 of 1969), Which drew its legal authority from the 1936 Native Trust and Land Act. This Proclamation does not appear to have greatly changed the system of land administration or tenure, but has codified existing practice.

Proclamation R188 gave the Bantu Commissioner authority to grant PTOs on arable and residential land in the areas falling under his authority. The (Commissioner could, if land was available and after consultation with the tribal or community authority, the chief or the headman, allocate land to the following categories of people:

- A black person who was the lawful but unregistered ocaupier of any Trust land for arable or residential purposes.

- The male head of a black household, or the widowed female head of a black household, who would not become the holder of more than one piece of land.

- Any church or missionary society for occupation by! a black minister, preacher, or evangelist in its employ.

Land allocations other than for arable and residential purposes had to be approved by the Secretary for Bantu Admiristration and Development. The extent of land that could be allotted under this system could not exceed half a morgen for a residential plot and four morgen for an arable plot. The holder of such a right was required to pay a nominal rent to the Bantu Authorities Trust Fund. Permission to vacate a plot for a period exceeding 1 year, but not exceeding 2 , had to be obtained in writing from the Commissioner.

Upon the death of a registered PTO holder, the residential or arable allotment reverted to the commonage for reallocation. Any attempt by the registered holder to leave a testament 
passing his holding to a family member had no force in law and any such testament was deemed void. The wife of a deceased occupier could remain on the land until her death, but the land remained registered in the name of the former male head of the household.

Proclamation R188 further gave the Minister of Bantu Administration and Development the power to terminate any or all rights in any arable or residential allotment 'whenever in his discretion he deem it expedient in the interest of the State or the Trust or in the general interest to do so" [Section 58]. The Commissioner had to give notice to th $\$$ holder of the PTO whose rights were being terminated and there was no system of appeal from such an order. The person whose rights were cancelled under this section had, however, a right "to be allotted other land in an area set aside for residentialpurposes or elsewhere in a Bantu area ...and in addition be paid such compensation in money out of Trust funds as the Bantu Affairs Commissioner shall assess."

The PTO certificates held by plot holders at the Arabie-Olifants scheme combine an allocation of irrigated land with a residential stand and, in a minority of cases, permission to graze a set number of cattle (typically five or six). Only the measure of land to be allocated, not the precise location, is recorded, along with the farm name. The residential stand number and the corresponding irrigated plot number are, however, written on the top right-hand corner of the certificates. These PTO certificates are today the main visible claim to the land, even though they are technically obsolete since the repeal of the 1936 Act in 1991 (Abolition of Racially Based Land Measures Act, 199|1).

The question of payment for land could not be resolved with any certainty. A number of informants stated that annual fees must be paid by landholders, either to the tribal authority or the Department of Agriculture. Amounts of R5 per hectare and R12 per plot were mentioned. In addition, officials of the Department of Agriculture reported that plot holders at Veeplaats and Goedverwacht pay an annual fee of R50 to the Department. It was not possible to determine how effectively these fees are collected or the consequences, if any, of nonpayment.

Thus, the formal tenurial arrangements on the Arabie-Olifants scheme at the time the current residents took up occupation can be summarized as follows:!

- Land was state-owned and allocated to tribal communities, divided into varying numbers of villages.

- Household heads (men and their widows) were allocated residential and irrigated land, plus a share of communal grazing. 
- Government afficials who communicated with the plot holders through their chiefs, made allocations.

- All land was granted under permit (PTO) in usufruct, and could, in theory, be withdrawn by the state for any reeson, although in practice such allocations were for life.

- Inheritance of land with in families was not sanctioned by the law, but was tolerated in practice.

- Land could not be sold leased, or otherwise alienated.:

\subsection{Popular Perceptions of Land Allocation and Tenure}

According to popular perceptiors of the land allocation prołess, people in need of land, for residential or arable purposes must first approach their village headman who may, at his discretion, refer the application tc the tribal authority (also referred to as the tribal council) that may approve, amend, or refuse tr e application. The tribal authority is under the jurisdiction of a tribal chief, who is not usually involved in its day-to-day proceedings. According to one chief at the Arabie-Olifants scheme, anyore applying for land may appeal to the chief for a repeal of a decision of the tribal authority, anc a chief has the power to invalidate any decision of the tribal authority. Other chiefs suggested $\bar{\varepsilon}$ more consensual model,; whereby the chief and the tribal authority reach decisions jointly. In practice, it is extremely rare for a tribal authority and a chief to be in open disagreement.

Once the chief and tribal authorily approve an application,!and a specific piece of land has been allocated, the chief gives a letter to the applicant to be taken to the local Magistrate's office, where an official PTO certificale will be issued. In the case of rain-fed arable land (i.e., land off the official irrigation scheme) and residential sites, the portion will usually be surveyed by the Department of Agriculture prior to the PTO certificate being issued. There was no suggestion that a Magistrate had the fower to refuse a properly presented request from a chief to issue a PTO certificate

Virtually all respondenss (chiefs anc commoners) agreed that the ultimate power to allocate land rests with the chief, although many qualified this with statements such as 'the chief and the tribal authority' or 'the chief, on behalf of the community.' Chiefs were generally seen as bound by the need to consult the community or matters of importanceiand to protect the interests of all community members. There was no suc gestion that chiefs were bound by democratic norms, but there was a strong sense that a chiet was not free to act in an authoritarian manner or solely in his or her own interest. the chiefs were widely seen as having a responsibility to provide land for their subjects, and both chiefs and commoners expressed frustration that there was not 
always sufficient land for all those who wanted it. Thus, the theoretical (or traditional) right of every household to an arable plot must be understood in the context of land scarcity, betterment-era zoning, and predetermined plot sizes on the formal irrigation schemes, all of which place limits on the power of the chiefs to allocate land and the rights of subjects to acquire it.

Some minor disagreement was found around the question of who is entitled to apply for land, but a broad consensus could be discerned. Those with the strongest entitlement to land were male heads of households - that is, married men with their own homesteads. Such men were entitled to apply for land on their own behalf. All other social groups were seen as having lesser degrees of entitlement, the extent of which varied somewhat between respondents. Married women were considered by many to be entitled to apply for land, but were obliged to do so through their husband or other male relative. Unmarried women or widows with children and their own homestead were also seen as entitled to apply for land, but most respondentsincluding women themselves - believed that they should do so through a male relative. A number of respondents mentioned minimum ages at which such women became eligible, the highest, from Masemola Triba| Authority, being 50 years of age.| No such age limits were mentioned with regard to married men.

Unmarried people, without children or homesteads of their own, were generally considered ineligible to apply for land. A number of respondents, including one chief, suggested that exceptions could be made for unemployed young men who wanted to practice agriculture, but no such exceptions could be made for young women. The chief in question reported that if such a young man approached him, he would not grant him land of his own, but would persuade some other person to share land with him until he became entitled to land of his own. Thus, family status, gender, and age all contribute to a widely agreed hierarchy of entitlement to land, with married, older men at the top and unmarried, younger women at the bottom.

Most of the households, which obtained plots at the beginning of the scheme, would appear to have held on to them to this day. Substantial numbers of households (the precise number could not be determined) are today without access to land, and thi\$ can probably be attributed to an expansion in the number of households over time, whether/due to natural increase or inward migration. With the exception of one area (Masha), no evidence could be found of households losing rights to land, although there were reports of households occasionally surrendering their plots. Thus, despite the elaborate rules governing allocation, there would in fact appear to be very little turnover in plot holding on the scheme. This is supported by an examination of PTO records held in the ARDC office at Veeplaats. For example, on the farm De 
Paar, with a total of 50 plots, just three changes have been recorded for the period since 1983; two in 1992, both to people with surnames different from those of the original plot holders, and one in 1998 recorded as a transfer to 'the only widow' of a deceased plot holder. On Veeplaats itself, with 121 plots, in the period since 1987, 4 plots have'been transferred to people with surnames different from those of the original plot holders, 5 more from men to what appear to be their widows and 2 from women to their daughters!

As irrigated blocks are allocated to specific communities and every household has, in theory, a right to a plot, the main limitation on access to land is the number of irrigated plots available. The only other (hypothetical) reason cited, by a chief, for refusing land to a qualified applicant, other than land scarcity, was 'disloyalty to the chief,' which was explained as the refusal to accept the authority of the chief. In practice, however, no such case could be recalled by any of the informants.

As noted above, irrigated plots generally remain within the possession of a single household indefinitely. On the death of a plot holder, possession usually passes to a close relative, either a wife, son, daughter, or daughter-in-law. No mention was made of land passing from a wife to a husband. No single pattern of inheritance could be identified, and it appeared to be influenced by who, within the household, was actually using the land iand by the composition of the household at the time of transfer. According to one chief, the order of preferencefor inheritance from a male plot holder was first his senior wife, followed by any junior wife, then a son, and finally a daughter. A woman would be expected to leave her plot to her son, if one lived with her, or else to her daughter of daughter-in-law. Women tended to inherit land if the men in the households were not interested in using it themselves, or if they (the women) had already been using it. Primogeniture does not apply, but the eldest offspring still resident within the parental home would appear to have a strong claim on household land. In practice, land often passes to the last-born, all other siblings having left to form their own households.

Identifying the actual 'plot holder' within a household was not entirely straightforward, for a number of reasons. First, official records (e.g., PTOs) are not always updated following the death of a registered plot holder and, over time, there would appear to be a growing discrepancy between the written record and actual practice. Second, the registered owner, if alive, may not be the person actualiy using the plot. In particular, there would appear to be a tendency for plots to be registered in the name of men when they are actually used by women.

\footnotetext{
${ }^{4}$ These judgements are made either on the basis of notes in the official record or by comparing ages, names, and surnames of the yarious parties.
} 
It is impossible to say without further research whether this indicates a change in practice within households over time, with and use transferring from men to women, or an inherent bias within the land registrationsystem, whereby land is registered in the names of men even though it is to be used by women. Overall, the majority of plots on the Arable/Olifants scheme are registered in the names of men, although the majority of users are undoubtedly women.

Formal transfers of land between households would appear to be extremely rare, although

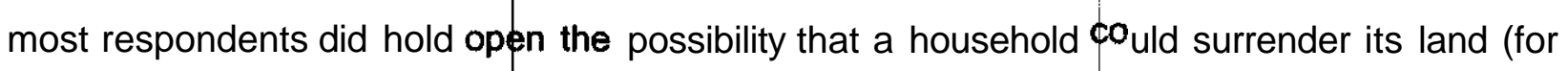
whatever reason) and that the chief could reallocate it. Informal, te $\mathrm{m}_{\text {porary }}$ exchanges of land,

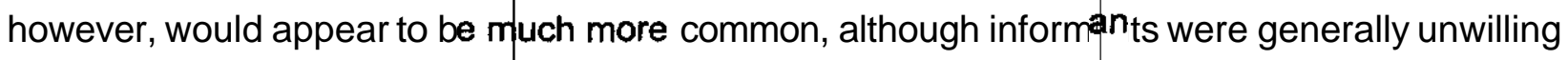
to discuss the matter in any detail. While many respondents claimed it could never happen, others admitted it was a common practice but refused to divulge any details. According to government officials on the scheme, the most common form of transaction was where someone would request the use of a plot from a neighbor for a single cropping season, and in return would plow the land on behalf of the plot holder the next season. Other transactions mentioned were temporary sharecropping arrangements, whereby a portion of the crop would be handed over to the official plot holder after harvest. Cash payment for land (i.e., rental) was said to be rare, but possible on occasion \$- a charge of R50 for a 1.28 hectare plot for one season was mentioned by one extension officer. Overall, however, respondents were agreed that the details of any arrangementto share land were a private matter between the two parties concerned, and that it was best not to publicize the fact that one was sharing one's Pnd with others.

The precise reasons for this reticence were not clear, but ther was a general feeling that land-sharing arrangements would not meet with the approval of the powers-that-be. There is a common perception among those on communal land that, because land is allocated on the basis of need (at least in theory), continued security of tenure requires that a plot holder is seen to be using his or her plot. Indeed, many tribal communities in adjoining areas have rules that set time limits on how long a piece of land can remain unused (typically about 3 years) before it reverts to the community for reallocation. Within this context. long- ${ }^{e r}$ n leasing-out of land could be interpreted as a lack of need for land, and could therefore we ${ }^{\text {ak }}$ en the rights of the official landholder. The leasing-in of land could also be perceived as in attempt to bypass the established channels for the acquisition of land and thus reflect $b^{\text {ad }}$ ly on the lessee or tenant. The authorities involved in the provision of agricultural servic ${ }^{\mathrm{eS}}$, namely ARDC and the Department of Agriculture, als 0 expressed some antipathy to lanld sharing, and plot holders were under the impression that it was still forbidden. The reasons for this would appear, in part, to be simply bureaucratic, in that ARDC administrators encounter difficulties in cases where the 
name of the official plot holder does not correspond to the name of the person being charged for services. Beyond this, however, it would appear that scheme officials in general have, over many years, discouraged land sharing as part of their mission to promote 'good farming practice' that, in the South African case, invariably carries a strong bias towards a system of 'owner-occupiers' and the concept of 'one-man-one-plot.'

Informants at Arabie-O|ifants supplied a range of response $\$$ to the question "Who owns the land?" The most common response was 'the plot holders' or 'the farmers themselves,' an opinion shared by plot hoiders and at least by one chief. The next most common response was that the land belonged to the 'the chief,' 'the community,' or 'the tribe,' or some combination of these. One chief stated that the land belonged to 'the community living under' the chief,' emphasising the indivisibility of the two. A minority of informants mentioned 'the government' or 'the Trust' as having a stake in the land, but usually qualified this by reference to the moral right of the inhabitants as 'the real owners.'

The sense of ownership expressed by most informants can be linked to the strong sense of tenure security felt by plot holders. In the study by Mpahlele, Malakalaka, and HeddenDunkhorst (1999), 87 percent of plot holders on Sepitsi, 59 percent of those at Veeplaats, and 100 percent of those on Veeplaats Center Pivot Number 2 felt their tenure was secure. Objectively speaking, landholders would indeed appear to be secure, given the long occupancy of most plot holders, the low turnover of plots, the freedom to bequeath land to one's chosen heir and the absence of reports of people losing rights to land (with the possible exception of the Masha area, see below). Many plot holders were conscious, however, of at least some of the differences between the communal tenure system under whlich they live and the freehold system prevailing in the 'white' areas. This gave rise to a number of comments along the lines of 'we feel insecure because we don't have title deeds,' although most informants expressed their satisfaction with the PTO system. On further examination, all oflthose advocating title deeds, in fact, supported the continuation of the communal system, in thatithey did not believe that people should have to pay for land, or that people should be free to sell land to others. Rather, they wanted the same legal status as 'white' landowners, both as a bulwark against arbitrary interference by the state (ap experience common to all the communities at Arabie-Olifants) and as a means of accessing credit from commercial lenders. The apparent contradiction between land as collateral and as a non-tradable commodity was not raised.

Overall, it would appear that plot holders and community leaders at Arabie-Olifants wish to maximize the tenure security and access to commercial service of individual plot holders, while rejecting the concept of a free market in land. Although not everyone was supportive of the 
current tribal-based system, there was strong support for some degree of 'communal' control over the allocation of land and for restricting access to land to members of the immediate community.

\subsection{Changes Affecting Landholding since the Beginning of the Scheme}

The land tenure system described above remains more or less intact today, albeit with some modifications. The main changes over the 25 years to 1997 (prior to the dramatic decline of the

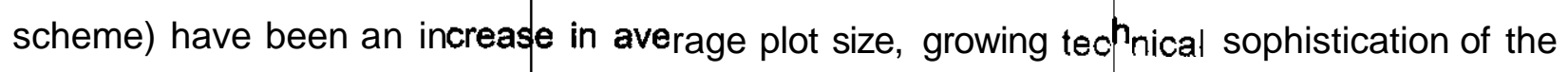
irrigation system, and what would appear to be a substantial rise in the proportion of plots held by women. ${ }^{5}$ The rate of change in landholding has, however, been limited by the lack of formal mechanisms for reallocating land (i.e., to people outside the households of the original plot holders), and by the fact that reallocation can only be made withirl the communities (villages) located on particular farms. Where change has occurred, it has generally been linked to major changes in the design of the irrigation scheme itself. Thus, apart from the original allocation of land in the 1950s and 1960s, allocation on the Arabie-Olifants scheme has tended to be a somewhat sporadic affair, and the information and opinions gathered on the allocation process need to be seen in this light. While many informants were able to supply detailed descriptions of the (theoretical) process wherepy people applied for and were allocated plots, few were in a position to provide instances where this process had actually been applied.

The Arabie-Olifants irrigation scheme has been extended, and the infrastructure upgraded, in a number of phases. The first phase of the scheme can be considered to be what existed on the scheme when the communities now present first took up occupplion, in the late 1950s and 1960s. This was a gravity-fed canal system, utilizing furrow and floof irrigation. A standard plot size of 1.28 hectares was the norm and plots were allocated to 'head\$-of-households' who were largely, if not entirely, male. In the years that followed, the profile of flibt holders would appear to have become more female, as plots were transferred to women within the existing households, and some new plots were allocated directly to women.

In the early 1980s, the Government of Lebowa implemented a major expansion of the scheme. The farms Veeplaats, Goedverwacht, and Nooitgezien that had previously been used for grazing were now put under irrigation for the first time, using sprinklers. Sprinklers were also installed on farms such as Strydkraal and Wonderboom, which had previously been using

\footnotetext{
${ }^{5}$ The absence of comparative data for the period prior to 1983 meant it was impossible to quantify this change with any certainty.
} 
furrow or flood irrigation but others, such as Hindostan and Coetzeesdraai, continued to use flood irrigation. A number of Center pivot irrigation systems were also installed on the farms Goedverwacht, Veeplaats, and Strydkraal. Further upgrading of the technology occurred in 1987, when pumps were installed at Nooitgezien to pump water from the Olifants river and at Goedverwacht to pump water from the Ngwaritsi river (a tributary of the Olifants, fed by the Piet Gouws dam).

The significance of these developments, from a land-tenure perspective, is that they brought a substantial increase in average plot sizes, as well as ini the total number of plots, and necessitated the reorganization of plot boundaries. This, in tutn, created an opportunity for the reallocation of plots among members of the affected communities. The biggest group of farms affected by these changes were those under Chief Masemola. On the newly created irrigation scheme at Veeplaats, the standard plot size was 2.5 hectares, virtually double the previous norm. Access to irrigated land for members of the Masemola community was greatly increased with the addition of $121 \mathrm{n}$ ww plots on Veeplaats alone. In addition, 30 plots, each 5 hectares in extent, were created under the 3 center pivots on the farm Goedverwacht to accommodate an emerging 'elite' of more commercially orientated farmers. At least 2 of these plot holders, both men, have since been able to acquire additional plots on the center-pivot schemes, giving them holdings of 10 hectares eqch. Five out of the current 28 plots holders are women, each with a plot of 5 hectares.

On farms such as Gqtaan and Wonderboom, where plots were redesigned to suit the sprinkler system, informants were of the opinion that virtually all of the original plot holders were reallocated plots, and some additional households received plots on the additional land brought under irrigation. The only households to lose land, according to the tribal authority, were those that were no longer interested in farming, although this could not be independently verified. Further downstream, at Strydkraal and Mooiplaats, the reorganization of holdings would appear to have led to the dispossession of some plot holders, particularly members of the neighboring Nchabeleng community. As this matter is now the subject of legal proceedings, and was not investigated in depth as part of this study, we will not attempt to draw any conclusions. On the basis of a number of different accounts. however, it can be said that a) these farms, falling under Chief Masha, appear to be the only area where members of two different tribal communities-Masha and Nchabeleng-shared the same farms and b) somewhere in the 1980s, the members of the Nchabeleng community withdrew or were excluded from the Masha area. 
Apart from the increase in average plot sizes, and the increased supply of irrigated land, the biggest change in landholding patterns arising from these developments was a reported increase in the proportion of plots registered in the names of women. According to the Masemola Tribal Authority, a deliberate effort was made by the th n,chief to allocate plots to women in cases where they were to be the principal cultivators. This was intended to strengthen women's control over their plots and to reduce conflicts between husbands and wives over the fruits of the women's labor. Recent studies conduced at Veeplaats suggest that 59 percent of plots are de facto controlled by women (Mpahlele, Malakalaka, and Hedden-Dunkhorst 1999), although an examination of the available PTO records would suggest that the proportion actually registered in women's names is closer to 40 percent: On other farms, the estimated proportion of plots registered in women's names ranged from 20 percent at Gataan to 26 percent at Wonderboom.

Another development that has favored the acquisition of land by women has been the rise of the so-called garden plots adjacent to the main irrigation scheme. Five of these were identified on the farms in question: two at Wonderboom, started in 1988 with support from an NGO called Operation Hunger; one at Vlakplaats, started in 1993 with support from the Department of Health and Welfare; and two at Nooitgezien. Another, the largest by lfar, is the Sepitsi scheme. on the farm Badfontein, across the Olifants river from Veeplaats. This was a joint initiative started in 1996 by the local community, ARDC, and the local Department of Agriculture on land falling under Chief Mphahlele.

All of these holdings are extremely small. At Wonderboom, 44 persons share one plot of 0.7 hectare (equivalent to 0.016 hectare per person) and 50 person $\$$ share another plot of 2 hectares (equivalent to 0.04 hectare per person). Both of these sch $\epsilon^{\mathrm{m}} \mathrm{m}$ es are largely composed of women members ( 43 out of 44 and 47 out of 50 , respectively). On the Mamakau scheme, on Vlakplaats, 17 women share approximately 1.75 hectares, equivalent to 0.1 hectare each. At Sepitsi, where a total of 81 plot holders have individual holdings of 0.12 hectare each, a recent study (Mpahlele, Malakalaka, and Hedden-Dunkhorst 1999) estimated that 70 percent of plot holders were female.

The formal land tenure situation on these garden schemes differs from that on the larger irrigation plots of the Arabie-Olifants scheme. The land was formally allocated by the Chief, and surveyed by the Department of Agriculture, and a single PTO was issued to each group. Such

${ }^{6}$ PTO certificates were found for eight farms, with some certificates missing. Th e certificates indicate the names but not the sex of the registered plot holders. Estimates of the sexual division of land are based on an analysis of first names but remain imprecise due to the prevalence of nonspecific first names. 
schemes are a recent deyelopment, and it is not clear what degree of tenure security they offer their members.

One further change to the landholding pattern on the Arabie-Olifants scheme has been the rise of 'informal' (or 'private') irrigation plots adjacent to the river and to the main irrigation canal. A handful of such plot hфiders have PTOs granted by the respective chiefs, but most would appear to be unapproved. This was reported to be a recent phenomenon, which informants linked to the decline of production on the formal scheme and the breakdown of local authority structures during the political turmoil after 1990. In a few cased, water is being pumped from the river, but most plot holders rely on unauthorized ('illegal') connections to the main canal: The rise of 'informal' irrigation could be seen as evidence of a demand for land, but this must be set against the collapse of production on much of the formal scheme. 


\section{Chapter 4}

\section{Land Tenure Reform: Now and in the Future}

\subsection{Arguments for Tenure Reform}

The evidence from the Arabie-Olifants scheme would suggest that there is a high degree of satisfaction with the existing tepure system among plot holders and community representatives (elected councillors and tribal leaders) and little demand for radical change to the system by which people acquire land, the conditions under which people hold land, or the (largely unwritten) rules governing the transfer of land.

Pressure for tenure reform is coming almost entirely from two external sources, both stemming from the unilateral withdrawal of government Services to the scheme. The first of these sources is the government itself, or more accurately the Northern Province Department of Agriculture, Land and Environment, in its role as custodian of the irrigation infrastructure and as the parent body of the Agricultural and Rural Development Corporation (ARDC). Faced with the imminent collapse of the ARDC, the Department is anxious to transfer responsibility for the upkeep (and possibly the ownership) of the scheme to the plot holders themselves. Before this can happen, it will be necessary to clarify the ownership not only of the land but also of the infrastructure and other assets that make up the scheme. The Department has, until recently, seen transferring ownership rights in land from the state to the Plot holders (probably as a collective) as a necessary step towards the transfer of the entire sch $\mathrm{h}_{\mathrm{m}} \mathrm{me}$.

The second factor propelling the tenure debate is the newfound need for plot holders to access production credit from commercial sources. Again, this stems from the withdrawal of credit facilities by the ARDC over the last 2 years and the failure of the authorities to make provision for the continuation of this and other services by alternative means.

Commercial banks in South Africa will not generally lend to farmers who cannot offer title deeds as collateral. The state-owned Land Bank, which includes the provision of credit to 'emerging' farmers in its mission, has also shown reluctance to lend to small-scale farmers on communal land. A transition from communal tenure to individual freehold is being promoted by many commentators as the solution to this problem, and the idea has been taken up by some small-scale farmers as well. What is not being addressed, however, is the creditworthiness of farmers currently holding land under communal tenure, It can be assumed that commercial lenders will take into consideration not only collateral but also issues such as financial history 
and ability to repay in deqiding whether or not to extend credit to small-scale farmers. Thus, a transition to freehold is unlikely to offer the panacea that many would suggest.

Research on the Arabie-Olifants scheme suggests that What the majority of plot holders want is permanent and secure tenure, and access to credit and other services on reasonable terms. The preference among all the plot holders and community leaders we spoke to was to achieve this within the current system of communal tenure, or with a slightly modified communal system. The elements of the current tenure system that would appear to have near-unanimous support are:

- the power of the community (through its leaders) to decide on the allocation of land

- that land should nejther be bought nor sold

- that access to land be restricted to members of the immediate community

- that plot holders should have secure, life-long tenure and the freedom to bequeath their land to members of their families

- the power of the community to impose sanctions, ranging from verbal warnings to fines and repossession, on landholders who abuse their position, either by failing to use their land or by interfering with other users

This strongly suggests that, while plot holders are anxious to find solutions to their most pressing problems, most do not support, or have not conterpplated, a transition to freehold tenure or a market-based private-property system. Clearly, this presents problems for those advocating the use of land as collateral and points to the need to consider alternative forms of credit.

Within the communal tenure system there is certainly room for reform, without necessarily compromising the features of the current system that community members find most desirable. In the area of land allocation, it was clear that elements of the community were not happy with the power of the tribal leaders and the way it is exercised. Discussions with the elected local councils (TLCs) revealed considerable dissatisfaction. especially among the youth and the landless, many of whom would appear to feel excluded by the current tribal leadership. This suggests the need for a more democratic or inclusive process whereby different elements within the community, not only those on good terms with the chiefs regarding communal land. It also suggests the need to relax some of the restrictions on the right to apply for land, especially for women and young people. 
Land registration is another area in need of urgent reform. The issuing of PTOs officially ceased with the abolition of the governing legislation in 1991. Nonetheless, some chiefs and magistrates have continued to issue PTO certificates since then but this has been without legal authority. Pending the introduction of new legislation, there is currently no legal mechanism for registering new plots on communal land, or transferring land to new plot holders. Although the legal position is far from clear. it would appear that existing PTO certificates (those issued in 1991 or earlier) still carry some legal weight. The national government has declared its intention of abandoning the system of permits in favor of one that recognizes the underlying rights of landholders to communal land put it has yet to legislate these rights.

\section{Options for Tenure Reform under Current Legislation}

Current legislation and the government's Land Reform Prog $\{m m e$ offer a number of possibilities for those occupying communal land, but none would a pear to offer much hope to those on the Arabie-Olifants scheme. The forthcoming Land Righ (Bill is expected to contain more far-reaching proposals.

The South African Land Reform Programme is commonly described as having three legs: Restitution, for those who can prove they were unfairly deprived of their land rights since 1913. Redistribution, which assists communities to acquire land through the open market. Tenure Reform that aims to provide tenure security to those who had been denied it under the previous regime. Of these, tenure reform has received the least attention to date and has yet to bring significant change to the millions of people living under communal or informal tenure systems.

The legal basis for tenure neform (as applicable to people living and working on communal land) is composed of the following acts.

- The Upgrading of Land Tenure Rights Act, 772 of 1991, introduced by the former regime, allows for the 'upgrading' of PTOs to title deeds (or Deeds of Grant). Amendments by the ANC-led government since 1994 mean that, in practice, this now applies only to residential or business sites in urban areas and is not applicable to agricultural land in communal areas.

- The Interim Protection of Informal Land Rights Act, 31 of 1996, (IPILRA), is intended to protect people with insecure tenure from losing their rights in land, pending the introduction of long-term tenure reform measures (i.e., the Land Rights Bill). This act gives legal recognition to all long-term occupiers of communal land, regardless of the type of permit or permission they hold. It does not provide for any change in tenure. but 
does set down procedures that must be followed by anyone wishing to develop or dispose of communal land or otherwise affect the status; of established occupiers.

- The Communal Property Associations Act, 28 of 1996, establishes a new form of legal body (a Communal Property Association, or CPA) through which people may collectively acquire, hold, and manage property in terms of a written constitution. To date, the Act has mainly been used by communities acquiring 'new' land under the Restitution or Redistribution programs, rather than as a means of changing the status of land already under occupation. Communal Property Associations generally acquire land in freehold and allocate use-rights to members based on agreed rules. The formal subdivision of land under a CPA, and the issuing of title deeds for individual plots, is a possibility, but is generally not encouraged.

Other recently introduced laws, such as the Land Reform:(Labor Tenants) Act, 3 of 1996 , and the Extension of Security of Tenure Act, 62 of 1997, also fall under the tenure reform banner, but are applicable only to occupants or tenants of privalely owned land.

Within this legislative framework, there is little or no opportunity for plot holders on schemes such as the Arabie-Olifants to achieve any change in their tenure position. The most important of these laws is probably the Interim Protection of Informal Land Rights Act (IPILRA), which gives blanket legal recognition to all established land users and effectively replaces the PTO system. This law did not feature in any of our discussions at thk Arabie-Olifants scheme, or with provincial officials, and it can be assumed to be widely' unknown among its intended beneficiaries. The legal vacuum createc by the abolition of the apartheid-era land laws, and with it the system of PTOs, is also widely unacknowledged. While: IPILRA does not grant any new rights to people on communal land, it does, for the first time, give legal recognition to those rights that have been estaplished through custom and practice, This includes not only exclusive rights to residency and arable plots but also shared rights such as the right to allow livestock to graze, collect firewood, or cut thatching grass. even where these rights overlap with the rights of others. An important aspect of the act is that while it redognizes the rights of individual occupiers, it also recognizes the rights of communities to administer their affairs in line with established custom and practice, as long as this is in keeping| with the provisions of the South African Constitution with regard to matters such as gender equality and due processes and compensation for those deprived of property rights. In the area of gender equality, in particular, IPILRA is clearly at odds with much established practice, but this has yet to be tested in the courts. 
With regard to the current \$ituation on the Arabie-Olifants scheme, IPILRA has relevance in that it sets out procedures that must be followed before any change in landownership or the rights of occupants can be made. Of particular importance is the requirement that all members of an affected community are consulted and their approval given before any changes to land rights can occur. As land on the scheme is vested in four tribal communities- Matlala, Mampana, Masemola and Masha. All the members of a group, not just the members who currently hold irrigated plots, would be entitled to a say in any changes to their portion of the irrigation scheme. Any attempt to transfer ownership of the irrigated plots to the current occupants, for example, could be seen as depriving non-plot holders of their right to access plots in the future and could therefore be illegal. On the positive side, IPILRA provides a mechanism whereby communities can, in an open and demoaratic manner, express their opinions and influence proposed changes in land use or landownership. While the act does not in itself initiate change, it does ensure that anybody, including the government, proposing change must first win the support of the community.

One other aspect of land reform that may be applicable to the Arabie-Olifants scheme is the Redistribution Programme. This allows for groups of beneficiaries to apply for a government grant (currently set at R16, 000 per househoid), subject to an approved business plan and a household income ceiling (currently set at R1, 500 per month). To date, redistribution projects have mainly involved the purchase of 'new' land from private landcwners on the open market. In theory, groups may also apply to purchase state-owned land but, in the Northern Province at least, the government has not shown a willingness to divest itself of state land for these purposes.

Finally, it is worth noting that restitution, the third leg of land reform, may also have an impact on the land rights of people in the Arabie-Olifants area, but not necessarily on the tenure situation on the scheme. At least one community, Masha, has lod? ${ }^{\mathrm{e}} \mathrm{d}$ a claim for the restoration of its former land in Mpumalanga, and at least one other community, the Phetwane Community,

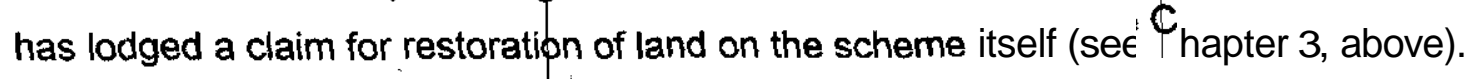

\subsection{Proposed Changes to Government Tenure Policy}

The centerpiece of the government's tenure reform policy is expected to be the Land Rights Act, which is intended to transform the communal tenure system. This proposed law, which was originally expected to come before parliament sometime in 1998, has encountered a number of delays, including stiff opposition from the chiefs, and is still at the drafting stage. It is now expected to be published in the form of a bill sometime towards the end of 1999. 
On the basis of statements emanating from the Department of Land Affairs, and some public consultations, it is possiple to discern the broad outline of the intended bill. First, it is expected to make permanent the rights of occupiers currently contained in IPILRA. Second, and more controversially, it will allow communities to choose the type af structure they want to administer land on their behalf. This poses an obvious threat to the, position of, the chiefs and tribal authorities. Third, it will dreate a mechanism whereby landholding structures can register their properly rights in a central registry. On the basis of this, and with the support of a majority of members, a landholding structure can apply for full ownership rights to the land in question, which would require a formal survey of the property. As a further step, landholding structures (i.e., communities) may also be able to apply to have their lifnd subdivided and registered as individual portions. Thus, the bill is expected to provide a methanism that will allow for, but not insist on, a gradual transition to formal landownership on the plart of communities and, if desired, allow them to move towards full (individual) private ownership.

The provisions contained in the Land Rights Bill could, in theory, transform the position of communities such as those found on the Arabie-Olifants scheme. They would give occupiers of communal land a right to acquire full ownership to 'their' land, subject only to consensus being reached within the community. The government would no longer be able to prevent the transfer of land to occupiers but would probably be able, in practice, to thamper the process considerably if it so wished. Given the weaknesses in the current legislative framework, and the absence of any clear policy direction on the handover of state land, it would appear that progress in the reform of communal tenure must await the passage of this bill.

\subsection{Conclusions}

This section summarizes the main findings of the study and sets out some possible directions for reform on the Arabie-qlifants scheme.

\subsubsection{Access to irrigated land}

Access to irrigated land on the Arabie-Olifants irrigation scheme is obtained primarily through membership of one of the four so-called tribal communities thal resides there, subject to availability. The chiefs and tribal authorities allocate land to heads-of-househoids for the exclusive and indefinite use of that household. Traditionally, the head-of-household is expected to be a man, but women can achieve the status of head-of-household through death of a husband, divorce, or, in the case of an unmarried woman, through establishing a homestead for herself and her children. Land is usually registered in the name of the head-of-household, 
although there is a trend towards registering plots in the name of users, most of whom are women.

Most irrigated land is in the form of plots on the formal irrigation scheme, ranging in extent from 0.7 hectare to 5.0 hectares. Recent years have, however, seen the rise of a number of the so-called food plots, of a much smaller scale, most of which are allocated to women. In most of these food-plot schemes, land is allocated by the chief to a self-managing group of would-be farmers, and access to land by individuals is obtained through membership of that group. There has also been a rise in private, or individual, irrigation away from the formal schemes. The chiefs also allocate such land although irrigation is commonly by means of unauthorized connections to the canal system.

\subsubsection{Land tenure}

Land, at the level of the individual plot, is entirely under the communal tenure system, a hybrid of traditional African practice and apartheid-era legislation. With the exception of two farms, the land is nominally owned by the state, but allocated for use purposes to specific communities ('tribes'). Occupiers may hold on to their land indefinitely as long as they use it and do not interfere with other users or antagonize the chief. They may bequeath their land to members of their family but may not sell, mortgage, lease, or subdivide it. Informal sharecropping and other land-sharing arrangements are tolerated on a temporary basis. There would appear to be no effective mechanisms for removing land from people once it is formally allocated. The communal system thus offers фccupants a high degree of tenure security although it continues to exclude them from access to commercial credit. The legislation that governs communal tenure was repealed in 1991, leaving a legal vacuum, but plot holders and local administrators are largely oblivious to this development.

\subsubsection{Position of women}

Women, who suffer from a range of discriminatory practices when it comes to formal land rights, work the majority of plots at the Arabie-Olifants scheme. This is rooted in African traditional views of women as subordinate to fathers and husbands, and was entrenched in the legislation that until recently governed the administration of communal land. Women gain access to land through applying to the tribal authority in their own name, through inheritance, or by arrangement with their husband or other male relative. All the tribal authorities on the scheme discriminate between male and female applicants, although the traditional bias against women holding land in their own right would appear to be diminishing. Wives have no automatic right to 
inherit land from their husbands and can, in theory, be displaced by other wives, offspring, or other relatives on the death of a husband. Recent legislative Changes give some protection to women in terms of sex equality laws but this has yet to make itgelf felt at the local level.

Women's desire for land is widely acknowledged on the scheme, and recent developments give grounds for optimism in this regard. At least one tribal authority has a policy of registering plots in the name of the user, regardless of sex, and membership of the small-scale food-plot projects initiated in the past 10 years is predominantly female. Such changes, however, raise the possibility of increased differentiation along gender lines, with women concentrated on smaller, subsistence-oriented plots and men dominating the larger. commercially oriented plots.

\subsubsection{Recommendations for reform}

The limited possibilities for tenure reform under current government policies are outlined above. Pending the introduction of new legislation, there is unlikely to be much change in the formal tenurial arrangements on schemes such as the Arabie-Olifants. Plot holders and community leaders were found to be largely content with the current communal system, but were concerned that the lack of title deeds excludes them from access to commercial sources of credit. There is strong support for continued community cdntrol of land and opposition to privatization of holdings or a market in land. Pressure for tenurial reform is coming mainly from the government, and the absence of western-style private property rights,appears to present a problem to many officials with responsibility for rural development.

Substantially improved access to land, for men and women, will require the enlargement of the areas available to black people. Despite the repeal of overtly discriminatory legislation, black people are still, in practice, confined to the relatively small and overcrowded areas of the former homelands. It is regrettable that the government's Land Restitution Programme, designed to restore the land rights of those who had been dispossessed under previous regimes, has yet to have any significant impact on landholding in the Northern Province. Some progress has been made under the market-based Redistribution Programme, but this has not yet impacted on the Arabie-Olifants area.

Without significantly improved access to agricultural support services, however, small black farmers will continue to struggle to make productive use of avaliable resources. The unilateral withdrawal of credit, plowing, pumping, and other services by government agencies in recent years has left many small-scale farmers in an impossible situattion and has led to the collapse of agricultural production in many areas. Any reform in landholding or tenure must be accompanied by a critical examination of the role of the state in creating an environment' 
whereby black farmers can oyercome the legacy of poverty and nderdevelopment and make full use of the land and water nesources available to them. 


\section{Bibliography}

Baber, Rupert. 1996. Current velihoods in semi-arid rural areas of South Africa. In Land, labor and livelihoods in Rural South Africa. Vol. 2 KwaZulu-Natal and Northern Province, ed. M. Lipton, F. Ellis, and M. Lipton. Durban: Indicator Press.

Beinart, William; Peter Delius; |and Stanley Trapido, eds. 1986. Putting a plough to the ground: Accumulation and dispossession in rural South Africa, 1850-1930. Jphannesburg: Ravan Press. Bembridge, T. J. 1986. An ove view of irrigation development in some less developed countries of Africa. Journal of ContemporaryAfrican Studies (5):1/2.

Bembridge, T. J. 1990. Agric ttural development in the developing areas of Southern Africa. Africa Insight 20(1).

Bennett, T. W. 1991. A sourcelbook of African customary law for Slouthern Africa. Cape Town: Juta.

Bennett, T. W. 1995. Human rights and African customary law under the South African constitution. Cape Town: Juta.

Bernstein, Henry. 1996. South Africa's agrarian question: Extreme and exceptional? Journal of Peasant Studies $23(2 / 3)$. Sppcial Issue on "The Agrarian Question in South Africa," ed. H. Bernstein.

Bromberger, Norman. 1988. Cash-cropping, subsistence, and grazing: Prospect for land tenure in KwaZulu. In Towards freehold: Options for landand development/ in South Africa's black rural areas, ed. Cross and Haines. Cape Town: Juta. 
Budlender, Geoff; and Jфhan Latsky. 1991. Unravelling rights to land in rural race zones. In A harvest of discontent; The land question in South Africa, ed. M. de Klerk. Cape Town: Institute for a Democratic Alternative for South Africa.

Bundy, Colin. 1979. The fse and fall of the South African peasantry. London: Heinemann.
Cobbett. M. 1987. The I nd question in South Africa: A preliminary assessment. The South
African Journal of Econo jics 55 (1).

Cooper, David. 1988. Ownership and control of agriculture in South Africa. In After apartheid: Renewalof the South African economy, ed. J. Suckling and L. White. London: James Curry.

Cooper, David. 1991. Agriculture in the Bantustans: Towards development policies. In A harvest of discontent: The land question in South Africa, ed. M. De|Klerk. Cape Town: Institute for a Democratic Alternative for South Africa.

Cousins, Ben. 1996. Livestock production and common property struggles in South Africa's agrarian reform. Journal of Peasant Studies 23 (2/3).

Cross, Catherine; and J. Richard Haines, eds. 1988. Towards freehold: Options for land and developmentin South Africa's black rural areas. Cape Town: Juta.

Cross, Catherine; and Peter Rutsch. 1995. Losing the land! Securing tenure in tribal areas. Indicator SA 12 (2).

Crush, Jonathan; Alan Jeeves; and David Yudelman. 1991. South Africa's labor empire: A history of black migrancy to the gold mines. Oxford: Westview Press

Davenport, T. R. H.; and K. S. Hunt. 1974. The right to the land: Documents on Southern African history. Cape Town: David Philip.

DBSA (Development Bank of South Africa). 1991. Development information: Region G; 6.1 agriculture and forestry. Midrand: Development Bank of Southern Africa. 
$D B S A$. 1993. Statistics on living standards and development regional poverty profile: Eastern and Northern Transvaal. Halfwyay House: Development Bank of Southern Africa.

DBSA. 1994. South Africa's nine provinces: A human development profile. Halfway House: Development Bank of Southern Africa.

Delius, Peter. 1983. The land belongs to us: The Pedi polity, the| Boers and the British in the nineteenth century Transvaal. Johannesburg: Ravan Press.

Delius, Peter. 1996. A lion amongst the cattle: Reconstruction and resistance in the Northern Transvaal. Johannesburg: Ravan Press.

Department of Land Affairs (\$outh Africa). 1997. White paper on South African land policy. Pretoria: Department of Land Affairs.

Desmond, Cosmas. 1971. The discarded people: An account of African resettlement. London: Penguin.

de Wet, Chris. 1995. Moving together drifting apart: Betterment planning and villagisation in a South African homeland. Johamnesburg: Witwatersrand University Press.

Dubow, Saul. 1989. Racial segregation and the origins of apartheid in South Africa 1919-36. Oxford:Macmillan, in association with St. Antony's College, Oxford.

Fischer, A. 1987. Land tenure in Mhala: Official wisdom "locked up" in tradition and people "locked up" in development. Dovelopment Southem Africa 4 (3).

Haines, Richard; and C. R. Choss. 1988. An historical overview of land policy and tenure in South Africa's black areas. In Towards freehold: Options for land and development in South Africa's black rural areas, ed. Gross and Haines. Cape Town: Juta.

Haines, Richard; C. P. G. Tapscott. 1988. The silence of poverty: Tribal administration and development in rural Transkei. In Towards freehold: Options for land and development in South Africa's black rural areas, ed. Gross and Haines. Cape Town: Juta. 
Harrie Patrick. 1989. Exclusion, classification and internall colonialism: The emergence of ethnicity amongst the Tsqnga-speakers of South Africa. In The creation of tribalism in southern Africa, ed. Leroy Vail. London: James Currey.

Hendricks, Fred T. 1990. The pillars of apartheid: Land tenure, rural planning and the chieftaincy. Uppsala:University of Uppsala.

Hill, Christopher R. 1964. Bantustans: The fragmentation of South Africa. London: Institute of Race Relations and Oxford University Press.

Horrell, Muriel. 1973. The African homelands of South Afrida. Johannesburg: South African Institute of Race Relations.

Houghton, D. Hobart. 1973 , The South African economy. Londbn: Oxford University Press.

James, Deborah. 1985. Family and household in a Lebowa village. African Studies 44 (2)

Keegan, Timothy, J. 1986. Rural transformations in industrialising South Africa: The southern Highveld to 1914. Johannesburg: Ravan Press.

Lacey, Marian. 1981. Working for Boroko: The origins of a coercive labor system in South Africa. Johannesburg: Rayan Press.

study from Venda. Ph.D. piss. School of Oriental and African Studies, University of London.

Lahiff, Edward. 1997b. Land, water and local governance in \$outh Africa: A case study of the Mutale river valley. Mancldester: Institute for Development Policy and Management.

Leseme, R. M.; T. I. Fènyes; and J. A. Groenewald. 1980. Traditional and legal aspects influencing agricultural development in Lebowa. Development Studies Southern Africa 2(2). Pretoria. 
Letsoalo, Essy M. 1987. Land reform in South Africa: A black perspective, Johannesburg: Skotaville.

Levin. Richard; and Sam Mkhabela. 1994. The chieftaincy, land allocation and democracy in the central Lowveld. In Community perspectives on land and agrarian reform in South Africa, ed. $R$. Levin and D. Weiner. Report to the John D. and Catherine T. MacArthur Foundation, Chicago.

Levin. Richard; and Daniel Weiner. 1991. The agrarian question and the emergence of conflicting agricultural strategies in South Africa. In Towards a new agrarian democratic order, ed. S. Matlhape and A. Munz. Amsterdam: SAERT.

Levin, Richard; and Daniel Weiner. 1996. The politics of land reform in South Africa after apartheid: Perspectives, problems, prospects. Journal of Peasant Studies $23(2 / 3)$.

Levin, Richard; and David Weiner. 1997. From apartheid to development. In No more tears: Struggles for land in Mpumalanga, South Africa, ed. R. Levin and D. Weiner. Trenton, New Jersey: Africa World Press.

Lipton, Merle.1977. South Africa: Two agricultures? In Farm labor in South Africa, ed. F. Wilson, A. Kooy, and D. Hendrie. Cape Town: David Philip.

Lodge, Tom. 1983. Black politids in South Africa since 1945. Harlow: Longman.

Maloka, Tshidiso. 1996. Populism and the politics of chieftaincy and nation-building in the New South Africa. Journal of Contemporary African Studies 14 (2).

Marcus, Tessa; Kathy Eales; and Adele Wildschut. 1996. Down to earth: Land demand in the New South Africa. Land and Agricultural Policy Centre, Johannesburg. Durban: Indicator Press.

May, Julian. 1989. Differentiation and inequality in the Bantustans: Evidence from KwaZulu. SocialDynamics $13(2)$.

Mbeki, Govan. 1984. South Africa: The peasants' revolt. London: International Defence and Aid Fund for Southern Africa. Originally published by Penguin, 1964. 
Mclntosh, Alastair; and Anne Vaughan. 19€ State-oentred commercial smallholder development: Haves and have-nots in KaNgwane. DevelopmentSouthern Africa 12 (1).

Morris, M. L. 1976. The development of capitalism in South African agriculture: Class struggle in the countryside. Economy and Society 5 (3).

Mpahlele. R. E.; T. M. Malakaiaka; and B. Hedden-Dunkhorst. 1999. Potentialand constraints of smallholder irrigation in Sфuth Africa: A case study of the Olifants river irrigation scheme. Report prepared for the International Water Management Institute, Colombo.

Murray, Colin. 1987. Displaced urbanisation: South Africa's rural slums. African Affairs 86 (344).

Nattrass, Jill. 1988. The South African economy: Its growth and change. Cape Town: Oxford University Press.

Nattrass, Jill; and Julian May. 1986. Migration and dependency: Sources and levels of income in KwaZulu. Development Southern Africa 3 (4).

Nieuwenhuysen, J. P. 1964, Economic policy in the reserves since the Tomlinson Report. South African Journal of Economics $32(1)$.

Platzky, L.; and C. Walker. 1985. The surplus people: Forced removals in South Africa. Prepared for the Surplus People Project. Johannesburg: Ravan Press.

Robertson, Michael. 1989 Dividing the land: An introduction to apartheid land law. In No place to rest: Forced removals and the law in South Africa, ed. C. Murray and C. O'Regan. Cape Town: Oxford University Priess.

SAIRR (South African Institute of Race Relations). 1994. Race relations survey 1993/94. Johannesburg: South African Institute of Race Relations.

SAIRR. 1996. South African survey 1995/96. Johannesburg:, South African Institute of Race Relations. 
SALDRU (South African Labour and Development Research Unit). 1994. South Africans rich and poor: Baseline householdstatistics. Cape Town: SALDRU, University of Cape Town.

Shackleton, C. M. 1993. Are the communal grazing lands in need of saving? Development Southern Africa 10 (1).

Sharp, John; and Andrew Spiegel. 1990. Women and wages: Gender and the control of income in farm and Bantustan households. Journal of Southern African Studies 16 (3).

Sirnkins, Charles. 1981. Agricultural production in the African reserves of South Africa, 19181969. Journal of Southern African Studies 7(2).

Sirnkins, Charles. 1984. Wha has been happening to income distribution and poverty in the homelands? Second Carnegie inquiry into poverty and development in Southern Africa. Paper No. 7. Cape Town: South Afric n Labour and Development Research Unit.

Solinjani, S. B. 1986. The dypamics of land allocation in Transkei. Paper prepared for Land Tenure and Rural Development Workshop, Institute of Social and Economic Research, Rhodes University.

Starkey, Paul. 1995. Animal traction in South Africa: Empowering rural communities. Halfway House: Development Bank of Southern Africa.

Steenkarnp. H. A. 1989. Regional population estimates for 1989. Pretoria: Bureau of Market Research.

Surplus People Project. 1983. Forced removals in South Africa: Vol. 5. The Transvaal. Cape Town: Surplus People Project,

Tapson, D. R. 1990. Rural development and the homelands. Development Southern Africa. 7(4).

Thompson, Leonard. 1995. A history of South Africa. New Haven, Connectlcut: Yale University Press. 
Union of South Africa. 1/32. Report of the Native Economic Commission 1930-7932 (U.G. 22/1932). Pretoria: The G(vernment Printer.

Union of South Africa. 1955. Summary of the report of the Commission for the socio-economic development of the Bantu ${ }^{a}$ reas within the Union of Soufh Afrioa (UG 61/1955). [The Tomlinson Report] Pretoria:The Gov' ${ }^{\text {Fnment Printer. }}$

van der Waal, C. S. 1991 District development and closer settlement economy in Gazankulu. Development Southern Afrika 8 (3).

van Kessel, Ineke. 1993. From confusion to Lusaka: The youth revolt in Sekhukhuneland. Journal of Southern African Studies 19 (4).

van Vuuren, C. J. 1988. Community gardens as food producing units. Development Southern Africa 5 (1).

van Zyl, Johan; and Johan van Rooyen. 1991. Agricultural production in South Africa. In A harvest of discontent: The land question in South Africa, ed. M. de Klerk. Cape Town: Institute for a Democratic Alternative for South Africa.

Vink, N. 1986a. An institutional approach to livestock development in Southern Africa. Ph.D. Diss. University of Stellenbosch.

Vink, N. 1986b. Systems of land tenure: Implicafions for development in Southern Africa. Research Report No. 6. Halifway House: Development Bank of Southern Africa.

Watkinson. Eric. 1996. Enforced agricultural change in South Africa: The emergence of a small class of commercial African farmers. Master's Thesis. Development Studies, University of Natal.

Weiner, Daniel; O. Chime-e-Dan; and Richard Levin. 1994. Results of the CPLAR Bantustan socio-economic survey. In Community perspectives on land an $₫$ agrarian reform in South Africa, ed. R. Levin and D. Weirer. Report to the John D. and Catherine T. MacArthur Foundation, Chicago. 
Welsh, David. 1971. The roots of segregafion: Native policy olonial Natal, 1845-1910. London: Oxford University Press.

Westaway, Ashley. 1995. Land and local government: Policy paper 27. Johannesburg: Land and Agricultural Policy Centre.

Whiteford, Andrew; and Michael McGrath. 1994. The distributi $f$ income in South Africa. Pretoria: Human Sciences Research Council.

Wilson, Francis; and Mamphela Ramphele. 1989. Uproofing poverty: The South African challenge. Report for the Second Carnegie Inquiry into Poverty and Development in Southern Africa. Cape Town: David Philib.

Wilson, Monica. 1969. The Sdtho, Venda and Tsonga. In The Oxford History of South Africa, Volume I, ed. M. Wilson and L. Thompson. London: Oxford Unive ' Press.

Wolpe, Harold. 1972. Capitalism and cheap labor-power in South Africa: From segregation to apartheid. Economy and Sociefy I (4).

World Bank. 1994. South African agriculture: Structure, performs and options for the future. Washington D.C.: The World Bank.

Yawitch, Joanne. 1981. Betterment: The myth of homeland agriculture. Johannesburg: South African Institute of Race Relations. 